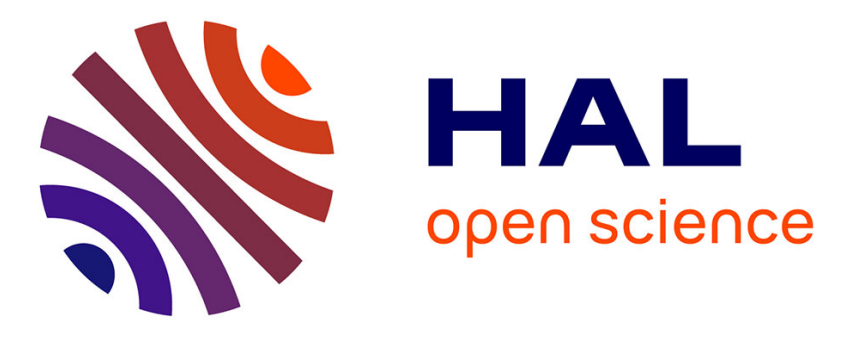

\title{
Surfactant-modified MFI-type nanozeolites: Super-adsorbents for nitrate removal from contaminated water
}

Layla El Hanache, Lion Sundermann, Bénédicte Lebeau, Joumana Toufaily, Tayssir Hamieh, T. Jean Daou

\section{To cite this version:}

Layla El Hanache, Lion Sundermann, Bénédicte Lebeau, Joumana Toufaily, Tayssir Hamieh, et al.. Surfactant-modified MFI-type nanozeolites: Super-adsorbents for nitrate removal from contaminated water. Microporous and Mesoporous Materials, 2019, 283, pp.1-13. 10.1016/j.micromeso.2019.03.049 . hal-02381511

\section{HAL Id: hal-02381511 \\ https://hal.science/hal-02381511}

Submitted on 22 Oct 2021

HAL is a multi-disciplinary open access archive for the deposit and dissemination of scientific research documents, whether they are published or not. The documents may come from teaching and research institutions in France or abroad, or from public or private research centers.
L'archive ouverte pluridisciplinaire HAL, est destinée au dépôt et à la diffusion de documents scientifiques de niveau recherche, publiés ou non, émanant des établissements d'enseignement et de recherche français ou étrangers, des laboratoires publics ou privés.

\section{()ㅜ(1)}

Distributed under a Creative Commons Attribution - NonCommercial| 4.0 International 


\section{Surfactant-Modified MFI-type Nanozeolites: Super-adsorbents for nitrate removal from contaminated water}

Layla El Hanache ${ }^{\mathrm{a}, \mathrm{b}, \mathrm{c}, \mathrm{d}}$, Lion Sundermann ${ }^{\mathrm{a}, \mathrm{b}}$, Bénédicte Lebeau ${ }^{\mathrm{a}, \mathrm{b}}$, Joumana Toufaily,d, Tayssir Hamieh $^{\mathrm{c}}$, T. Jean Daou ${ }^{\mathrm{a}, \mathrm{b}, *}$

${ }^{a}$ Université de Haute Alsace (UHA), CNRS, IS2M UMR 7361, F-68100 Mulhouse, France.

${ }^{b}$ Université de Strasbourg, France

${ }^{\mathrm{c}}$ Laboratoire Matériaux, Catalyse, Environnement et Méthodes Analytiques (MCEMA) - Université Libanaise - Campus Universitaire Rafic Hariri - Hadath - Lebanon

${ }^{d}$ Laboratoire de recherche sur les Etudes Appliquées au Développement Durable et Energie Renouvelable (LEADDER) _ Université Libanaise - Campus Universitaire Rafic Hariri - Hadath Lebanon

Three surfactant-modified zeolites with high external surface areas and small crystal sizes were synthesized and modified for the nitrate removal from contaminated water. ZSM-5 nanocrystals (NC), nanosheets (NS) and nanosponges (NSp) were synthesized by different processes in order to obtain nanocrystals and hierarchized zeolites with extended external surfaces. In order to obtain an anion exchanger system: Surfactant-Modified Nanozeolites $\left(\mathrm{SMZ}_{\mathrm{N}}\right)$, the as-synthesized zeolites were modified with a cationic surfactant $\left(\mathrm{HDTMA}^{+} \mathrm{Br}^{-}\right.$: hexadecyltrimethylammonium bromide). MFI-type zeolites with low external surface area and large crystal size (ZSM-5 microcrystals) were synthesized and modified with the same cationic surfactant for comparison with the $\mathrm{SMZ}_{\mathrm{N}}$ through nitrate removal. $\mathrm{N}_{2}$ adsorption/desorption, XRD, SEM, TEM, and TGA analyses were done on the raw and the calcined form of the synthesized zeolites in order to determine the textural and structural properties. For the three studied materials nitrate removal tests were carried out in a large initial nitrate concentration range $[0.8-40.5] \mathrm{mmol} . \mathrm{L}^{-1}$. Nitrate isotherms fitted Langmuir isotherm model and the maximum removal capacities were found to be $810( \pm 50), 1941( \pm$ 100), $2125( \pm 100)$ mmol. $\mathrm{Kg}^{-1}$ for $\mathrm{SMZ} \mathrm{Z}_{\mathrm{NC}}, \mathrm{SMZ} \mathrm{Z}_{\mathrm{NS}}$, and $\mathrm{SMZ} \mathrm{NSp}_{\mathrm{Np}}$, respectively. $\mathrm{SMZ} \mathrm{Z}_{\mathrm{NSp}}$ showed the highest nitrate adsorption capacities obtained till now with surfactant-modified zeolites (SMZ) materials. These systems were found to be ultra-fast adsorbent systems and the kinetics fitted the pseudo-second order model.

Keywords: Zeolite; Hierarchical zeolites; Surfactant-modified zeolites; Nitrate removal, Molecular decontamination.

* Corresponding author: jean.daou@uha.fr

$+33389336739$ 


\section{Introduction:}

In recent years, nitrate water contamination has become a serious problem to solve. Nitrates diffused from fertilized soils to the groundwater and wells, due to their high-water solubility and low soil adsorption affinity, are now causing 'Eutrophication': a severe water disturbance, which can induce a loss of aquatic life and lessen biodiversity [1,2]. The World Health Organization set a recommended limit of nitrate in drinking water at $50 \mathrm{mg} . \mathrm{L}^{-1}$ [3]. Above this value, nitrates can be reduced in the human body into nitrites developing different types of digestive cancers [4-6]. Removing or reducing nitrates from contaminated water has been studied quite a long time involving different routes and methods: biological (using bacteria, microbial and microbioalgal biomass for nitrate denitrification) [7-11], chemical (by the process of chemical reductions) [12-15], and most importantly, physico-chemical methods (by electrodialysis, ion exchange and reverses osmosis) [16-18]. Biological and chemical nitrate reduction are extensively studied in the literature. However, they are sensitive processes and can lead to incomplete denitrifications resulting in the formation of nitrites (very toxic compounds) once changing environmental conditions. Treatment by ion exchange was found to be the most efficient in this field since it presents a high selectivity for nitrate contaminants and does not require post-remineralization treatments after removal [19].

Aluminosilicate zeolites with negatively charged surfaces have been widely used in this approach after a surface modification with a cationic surfactant in order to obtain an anionic exchanger system. The hexadecyltrimethyl ammonium $\left(\mathrm{HDTMA}^{+}\right.$) [20] is mainly used as cationic surfactant because of its large size that prevents it to be adsorbed in the zeolite pore and its high thermal and chemical stability. The resulting surfactant-modified zeolite SMZ is suitable to remove pollutant anions from contaminated water [21-25]. Zhan et al. have studied the effect of the concentration of a cationic surfactant, the hexadecylpyridinium $\mathrm{HDP}^{+}$, in the formation of the SMZ system. They claimed that a double layer of $\mathrm{HDP}^{+}$ (admicelle) is formed on the surface of aluminosilicate zeolite once being in the optimal conditions ([cationic surfactant] > CMC) [22]. In details, the first layer of admicelle was formed thanks to the electrostatic interactions between the positively charged surfactant and the negatively charged aluminosilicate zeolite surface, the second one was bonded to the first by hydrophobic interactions (van der Waals). Admicelle positively charged at the end was stabilized by anions (counterions) that can be exchanged with nitrate and other anions in contaminated water.

Several SMZs have been tested through nitrate removal from contaminated water. The first tests were done by Guan et al. who studied the effect of hexadecyltrimethylammonium $\left(\mathrm{HDTMA}^{+}\right)$loading on the nitrate removal capacities of four SMZs obtained form natural zeolites from USA, Australia, Croatia, and China. Maximum nitrate removal capacities were found to be $3.5 \mathrm{mg} \cdot \mathrm{g}^{-1}$ after the maximum HDTMA ${ }^{+}$loading of $219 \mathrm{mmol} . \mathrm{Kg}^{-1}$ of zeolite and were evaluated 18 times higher than the capacities on the untreated zeolite surfaces [23]. Schick et $a l$. studied the effect of the presence of a competing anion in the environment of a SMZ made from clinoptilolite while removing nitrate from contaminated water $[24,25]$. The 
nitrate removal capacity was found to be $5.4 \mathrm{mg} \cdot \mathrm{g}^{-1}$ and no effect of competing anion was detected. Other systems such as kaolinite an aluminosilicate clay were tested through surface modification with $\mathrm{HDTMA}^{+}$then through nitrate adsorption. The results showed a nitrate removal capacity 125 times higher than this of the untreated clay $\left(1.5 \mathrm{mg} . \mathrm{g}^{-1}\right.$ and $0.012 \mathrm{mg} . \mathrm{g}^{-}$ ${ }^{1}$, respectively) [26].

In the last years, nanoporous hierarchical zeolites synthesized in the presence of dualporogenic surfactants were used in different applications due to their notable textural and structural properties [27-30]. One of the most important applications is their usage as high active catalysts in different acid-catalyzed organic reactions due to their high framework acidities and their large pore size distribution since they present both micro and mesopores [27, 31-33]. Moreover, thanks to their high external surface areas, hierarchical MFI nanosheets materials were used after surface modification (by $\mathrm{HDTMA}^{+}$) as surfactantmodified nanozeolites for the nitrate anion removal from contaminated water. These $\mathrm{SMZ}_{\mathrm{NS}}$ showed a nitrate removal capacity equals to $37.2 \mathrm{mg} \cdot \mathrm{g}^{-1}$ that is 6 times higher than modified SMZ obtained from a natural zeolite (clinoptilolite) with $6 \mathrm{mg} \cdot \mathrm{g}^{-1}$ [34]. Recently, our group has studied the effect of external surface on zeolite surface modification on three *BEA-type zeolites: microcrystals, nanocrystals, and nanosponges having initially 6,30 , and $116 \mathrm{~m}^{2} \cdot \mathrm{g}^{-1}$ as external surfaces. The results showed an increase in the surface modification (using the $\mathrm{HDTMA}^{+} \mathrm{Br}^{-}$) with the increase of the initial external surface. Nitrate removal capacity was found to be $83.3 \mathrm{mg} \cdot \mathrm{g}^{-1}$ on *BEA-type surfactant-modified nanosponges zeolites, the highest observed using surfactant-modified zeolite [35]. After removal tests, the final solution will be charged in bromide anion $\left(\mathrm{Br}^{-}\right)$, a non-toxic anions especially at low concentrations [36].

In this work we report the study of the nitrate removal capacity from contaminated water of four HDTMA ${ }^{+}$-modified ZSM-5 (MFI type) zeolites with different crystal sizes and external surface areas: two conventional zeolites (microcrystals MC and nanocrystals NC), and two hierarchical zeolites (nanosheets NS, and nanosponges NSp). First characterizations were done for all samples to evaluate their textural and structural properties, then they were modified with $\mathrm{HDTMA}^{+}$and the nitrate removal capacities were investigated in a very high nitrate concentration range starting from the limits fixed by the WHO; $50 \mathrm{mg} . \mathrm{L}^{-1}$ and going up to $1500 \mathrm{mg} \cdot \mathrm{L}^{-1}$.

\section{Experimental part:}

ZSM-5 zeolites were synthesized with different morphologies in order to obtain materials with different external surface areas. ZSM-5 microcrystals, nanocrystals, nanosheets and nanosponges were obtained as follows:

1) For ZSM-5 microcrystals (MC), a typical ZSM-5 zeolite with a coffin-shape morphology were synthesized by following the protocol described by Dhainaut et al. [37]. In a Teflonlined stainless-steel autoclave, $0.24 \mathrm{~g}$ of sodium hydroxide ( $\mathrm{NaOH}, 99 \%$, Riedel de Haën) and $0.062 \mathrm{~g}$ of aluminum sulfate $\left(\mathrm{Al}_{2}\left(\mathrm{SO}_{4}\right)_{3} .18 \mathrm{H}_{2} \mathrm{O}, 99 \%\right.$, RECTAPUR) were dissolved in distilled water. A mixture of $1.45 \mathrm{~g}$ of tetrapropylammonium hydroxide (TPAOH, $20 \%$, Fluka) and $0.17 \mathrm{~g}$ of sulfuric acid $\left(\mathrm{H}_{2} \mathrm{SO}_{4}, 96 \%\right.$, Fluka) was then added to the first mixture. 
After homogenization, $0.242 \mathrm{~g}$ of TEOS was finally added, then the resulting mixture with the gel composition $100 \mathrm{SiO}_{2}$ : $30 \mathrm{Na}_{2} \mathrm{O}$ : $1 \mathrm{Al}_{2} \mathrm{O}_{3}$ : 20 TPAOH: $18 \mathrm{H}_{2} \mathrm{SO}_{4}: 4000 \mathrm{H}_{2} \mathrm{O}$ was stirred at $1000 \mathrm{rpm}$ for $4 \mathrm{~h}$ at $60{ }^{\circ} \mathrm{C}$. The gel was then placed in a Teflon lined stainless steel autoclave and heated in a tumbling oven $(30 \mathrm{rpm})$ at $150{ }^{\circ} \mathrm{C}$ for 5 days. After cooling down, the solid product was recovered by filtration and washed with distilled water. The structuring agent was removed by calcination in a muffle furnace at $550{ }^{\circ} \mathrm{C}$ for $6 \mathrm{~h}$ under airflow with a ramp of $1{ }^{\circ} \mathrm{C} / \mathrm{min}$.

2) For ZSM-5 nanocrystals (NC) were synthesized under hydrothermal conditions without any additional altering, pre-seeding or pre-crystallization process. A high solid/liquid ratio (lower content of water as solvent) was used in order to obtain crystals with reduced particle size [38]. In a typical synthesis, a solution of $28.0 \mathrm{~g}$ of tetrapropylammonium hydroxide (TPAOH, $20 \%$, Fluka) and $6 \mathrm{ml}$ of $\mathrm{H}_{2} \mathrm{O}$ was prepared. Hereafter, $0.68 \mathrm{~g}$ of aluminum isopropoxide (AIP, $98 \%$, Alfa Aesar) was added and the solution was stirred for $20 \mathrm{~min}$ at room temperature. $1.37 \mathrm{~g}$ of sodium bromide $(\mathrm{NaBr}, 99 \%$, Aldrich) was added and a homogenous mixture was obtained after vigorous stirring for $20 \mathrm{~min}$ at room temperature, then $10.0 \mathrm{~g}$ of porous silica gel was added as the silica source. Further stirring of the mixture followed for $1 \mathrm{~h}$. The final molar composition of the mixture was $100 \mathrm{SiO}_{2}: 8 \mathrm{NaBr}: 2 \mathrm{AIP}$ : 20 TPAOH: $900 \mathrm{H}_{2} \mathrm{O}$. Subsequently, the mixture was transferred into a stainless-steel Teflon lined autoclave and put into an oven for $7 \mathrm{~h}$ at $170{ }^{\circ} \mathrm{C}$. After cooling down, the solid product was recovered by filtration and washed with distilled water. The crystals were dried at $100{ }^{\circ} \mathrm{C}$ overnight. The structuring agent was removed by calcination in a muffle furnace at $550{ }^{\circ} \mathrm{C}$ for $6 \mathrm{~h}$ under airflow with a ramp of $1{ }^{\circ} \mathrm{C} / \mathrm{min}$.

3) For nanosheets and nanosponges synthesis, specific dual-porogenic surfactants were prepared via organic synthesis: the $\mathrm{C}_{22^{-6} 6^{-6}}$ and the $\mathrm{C}_{18}-\mathrm{N}_{3}-\mathrm{C}_{18}$, respectively.

筑2-6-6: $\mathrm{C}_{22} \mathrm{H}_{45}-\mathrm{N}^{+}\left(\mathrm{CH}_{3}\right)_{2}-\mathrm{C}_{6} \mathrm{H}_{12}-\mathrm{N}^{+}\left(\mathrm{CH}_{3}\right)_{2}-\mathrm{C}_{6} \mathrm{H}_{13}$ is constituted by two quaternary ammonium groups (serving as structure-directing agent for the zeolitic framework) separated by one alkyl $-\mathrm{C}_{6} \mathrm{H}_{12^{-}}$spacer and terminated by one hydrophobic alkyl tails $\mathrm{C}_{22} \mathrm{H}_{45^{-}}$that inhibit crystal growth along $b$ axis. $\mathrm{C}_{22-6-6}$ is obtained after two steps as described in the protocol of Choi et al. [39]. ${ }^{1} \mathrm{H}$ NMR $\left(\mathrm{CDCl}_{3}, 300 \mathrm{MHz}, 25^{\circ} \mathrm{C}\right): \delta(\mathrm{ppm})\left[\mathrm{C}_{3}\right] 0.83(\mathrm{~m}, 6 \mathrm{H}) ; 1.3(\mathrm{~m}, 41 \mathrm{H}) ; 1.59$ $(\mathrm{s}, 4 \mathrm{H}) ; 1.71(\mathrm{~s}, 4 \mathrm{H}) ; 2.01(\mathrm{~s}, 3 \mathrm{H}) ;\left[\mathrm{C}_{2}\right] 3.36(\mathrm{~s}, 12 \mathrm{H}) ;\left[\mathrm{C}_{1}\right] 3.47(\mathrm{~m}, 4 \mathrm{H}) ; 3.72(\mathrm{~m}, 4 \mathrm{H})$. The yield of the synthesis was $90 \%$.

$\mathrm{C}_{18}-\mathrm{N}_{3}-\mathrm{C}_{18}: \mathrm{C}_{18} \mathrm{H}_{37}-\mathrm{N}^{+}\left(\mathrm{CH}_{3}\right)_{2}-\mathrm{C}_{6} \mathrm{H}_{12}-\mathrm{N}^{+}\left(\mathrm{CH}_{3}\right)_{2}-\mathrm{C}_{6} \mathrm{H}_{12}-\mathrm{N}^{+}\left(\mathrm{CH}_{3}\right)_{2}-\mathrm{C}_{18} \mathrm{H}_{37}$ is constituted by three quaternary ammonium groups (serving as structure-directing agent for the zeolitic framework) separated by two alkyl $-\mathrm{C}_{6} \mathrm{H}_{12}$ - spacer and terminated by two hydrophobic alkyl tails $\mathrm{C}_{18} \mathrm{H}_{37}$ (crystal growth inhibitors). $\mathrm{C}_{18}-\mathrm{N}_{3}-\mathrm{C}_{18}$ is obtained after three steps as described in the protocol of $\mathrm{Na}$ et al. [27]. ${ }^{1} \mathrm{H} \mathrm{NMR}\left(\mathrm{CDCl}_{3}, 300 \mathrm{MHz}, 25{ }^{\circ} \mathrm{C}\right): \delta(\mathrm{ppm}) 0.83(\mathrm{t}, 3 \mathrm{H}) ; 1.3(\mathrm{~m}$, $41 \mathrm{H}) ; 1.59(\mathrm{~s}, 4 \mathrm{H}) ; 1.71(\mathrm{~s}, 4 \mathrm{H}) ; 2.01(\mathrm{~s}, 3 \mathrm{H}) ;\left[\mathrm{C}_{2}\right] 3.36(\mathrm{~s}, 12 \mathrm{H}) ;\left[\mathrm{C}_{1}\right] 3.47(\mathrm{~m}, 4 \mathrm{H}) ; 3.72(\mathrm{~m}$, $4 \mathrm{H})$. The yield of the synthesis was $90 \%$.

ZSM-5 nanosheets (NS) were synthesized under hydrothermal conditions, as described by Ryoo et al. [39], by using a multi-quaternary ammonium surfactant: the $\mathrm{C}_{22-6-6}$ as dualporogenic surfactant in its bromide form (obtained as described previously). A typical synthesis was done in the same conditions and experimental procedure as described for the 
ZSM-5 microcrystals. The only difference was the replacement of TPAOH by $\mathrm{C}_{22-6-6}$. The resulting gel molar composition was $100 \mathrm{SiO}_{2}$ : $30 \mathrm{Na}_{2} \mathrm{O}: 1 \mathrm{Al}_{2} \mathrm{O}_{3}: 10 \mathrm{C}_{22-6-6}: 18 \mathrm{H}_{2} \mathrm{SO}_{4}$ : $4000 \mathrm{H}_{2} \mathrm{O}$. The mixture was stirred at $1000 \mathrm{rpm}$ for $4 \mathrm{~h}$ at $60{ }^{\circ} \mathrm{C}$. The gel was transferred in a stainless-steel autoclave with Teflon lined autoclave and put into a tumbling oven $(30 \mathrm{rpm})$ for 5 days at $150{ }^{\circ} \mathrm{C}$. The obtained crystals were recovered by filtration, washed with distilled water and dried at $80{ }^{\circ} \mathrm{C}$ overnight. The structuring agent was removed by calcination in a muffle furnace at $650{ }^{\circ} \mathrm{C}$ for $7 \mathrm{~h}$ under airflow with a ramp of $1{ }^{\circ} \mathrm{C} / \mathrm{min}$.

Concerning the synthesis of ZSM-5 nanosponges (NSp), as described by $\mathrm{Na}$ et al. [27], a crystalline mesoporous material was synthesized in the presence of the poly-quaternary ammonium surfactant $\mathrm{C}_{18}-\mathrm{N}_{3}-\mathrm{C}_{18}$. In a typical synthesis, $0.073 \mathrm{~g}$ of the source of aluminum: sodium aluminate $\left(\mathrm{NaAlO}_{2}, 56.7 \%\right.$ wt. $\% \mathrm{Al}_{2} \mathrm{O}_{3}, 39.5 \%$ wt. $\left.\% \mathrm{Na}_{2} \mathrm{O}\right)$ was mixed with $0.26 \mathrm{~g}$ of sodium hydroxide $(\mathrm{NaOH}, 99 \%$, Riedel de Haën) in $21.3 \mathrm{~g}$ of distilled water. Under stirring, tetraethoxysilane (TEOS, $98 \%$, Aldrich) was added dropwise as silica source and was mixed with a pure ethanol (ETOH, $99 \%$, Alfa Aesar) and stirred for $6 \mathrm{~h}$ at $60^{\circ} \mathrm{C}$. The resulting gel molar composition was $100 \mathrm{SiO}_{2}$ : $22 \mathrm{Na}_{2} \mathrm{O}: 2.5 \mathrm{Al}_{2} \mathrm{O}_{3}: 5 \mathrm{C}_{18}-\mathrm{N}_{3}-\mathrm{C}_{18}: 7100 \mathrm{H}_{2} \mathrm{O}$ : $800 \mathrm{EtOH}$. The gel was transferred in a stainless-steel Teflon lined autoclave and put into a tumbling oven $(30 \mathrm{rpm})$ for 5 days at $150{ }^{\circ} \mathrm{C}$. The obtained crystals were recovered by filtration, washed with distilled water and dried at $100{ }^{\circ} \mathrm{C}$ overnight. The structuring agent was removed by calcination in a muffle furnace at $650{ }^{\circ} \mathrm{C}$ for $7 \mathrm{~h}$ under airflow with a ramp of $1{ }^{\circ} \mathrm{C} / \mathrm{min}$.

\subsection{Characterization of the ZSM-5 zeolites:}

X-ray diffraction patterns of the different calcined ZSM-5 zeolites were recorded using $X^{\prime}$ Pert Pro diffractometer operating with $\mathrm{Cu} \mathrm{K} \alpha$ radiation $(\lambda=0.15418 \mathrm{~nm})$ equipped with an $\mathrm{X}^{\prime}$ Celerator real-time multiple strip detector (active length $=2.122^{\circ} 2 \Theta$ ). The powder pattern was collected at $22{ }^{\circ} \mathrm{C}$ in the range $3<2 \Theta<50^{\circ}$ with a $2 \Theta$ angle step of $0.017^{\circ}$ and a time step of $220 \mathrm{~s}$.

Scanning and transmission electron microscopy (SEM and TEM) images were taken on the calcined ZSM-5 zeolites with a scanning electron microscope (SEM) (Philips XL30 FEG) working at $7 \mathrm{kV}$ accelerating voltage and a transmission electron microscope (TEM) (Philips model ARM 200), operating at $200 \mathrm{kV}$, with a point-to-point resolution of $0.3 \mathrm{~nm}$, respectively.

Nitrogen adsorption/desorption isotherms were obtained at $-196{ }^{\circ} \mathrm{C}$ using a Micromeritics ASAP 2420 apparatus. The calcined samples were outgassed under vacuum for $1 \mathrm{~h}$ at $90{ }^{\circ} \mathrm{C}$ then overnight at $300{ }^{\circ} \mathrm{C}$ before the measurements. Microporous volumes $\left(\mathrm{V}_{\text {micro }}\right)$ were calculated using the t-plot method. Specific surface area was determined by using the BET method following Rouquerol creterium in the relative pressure range $0.001<\mathrm{p} / \mathrm{p}^{\circ}<0.007$, $0.004<\mathrm{p} / \mathrm{p}^{\circ}<0.052,0.004<\mathrm{p} / \mathrm{p}^{\circ}<0.054$, and $0.004<\mathrm{p} / \mathrm{p}^{\circ}<0.074$, for $\mathrm{MC}, \mathrm{NC}, \mathrm{NS}$, and NSp, respectively [40]. The mesopore size distribution of the zeolite NS and NSp were calculated using the model of Barrett-Joyner-Halenda (BJH) applied on the adsorption and desorption branch, respectively. 
Thermogravimetric (TG) analyses were carried out on a Mettler Toledo STARe apparatus, under air flow, with a heating rate of $5^{\circ} \mathrm{C} / \mathrm{min}$ from 30 to $800{ }^{\circ} \mathrm{C}$.

X-Ray Fluorescence analyses were done using a Magix PHILIPS spectrometer.

Nitrate ion concentrations were determined before and after removal tests using a UV-Vis Perkin Elmer $\lambda 35$ spectrometer at $\lambda=220 \mathrm{~nm}$. A calibration Beer-Lambert curve was drawn from a number of potassium nitrate solutions at different concentrations [0-40 mg.L $\left.\mathrm{L}^{-1}\right]$.

\subsection{Preparation of SMZ MFI-type materials}

As described in the literature, the surfactant modified zeolites $\left(\mathrm{SMZ} \mathrm{MC}_{\mathrm{MC}}, \mathrm{SMZ} \mathrm{Z}_{\mathrm{NC}}, \mathrm{SMZ} \mathrm{NS}_{\mathrm{NS}}\right.$, and $\mathrm{SMZ}_{\mathrm{NSp}}$ ) were prepared by treating $1 \mathrm{~g}$ of the as-synthesized zeolites with $20 \mathrm{~mL}$ of a 50 mmol. $\mathrm{L}^{-1}$ hexadecyltrimethylammonium bromide surfactant solution (HDTMA ${ }^{+} \mathrm{Br}^{-}$in demineralized water) at $60{ }^{\circ} \mathrm{C}$ for $24 \mathrm{~h}$. $\mathrm{HDTMA}^{+} \mathrm{Br}^{-}$is a cationic surfactant-quaternary ammonium salt with a critical micelle concentration (CMC) equals to $0.94 \mathrm{mmol} . \mathrm{L}^{-1}$ at $30{ }^{\circ} \mathrm{C}$ [41]. After achieving equilibrium, samples were recovered by filtration and washed with 50 $\mathrm{mL}$ of distilled water in order to remove the excess of the cationic surfactant $\left(\mathrm{HDTMA}^{+}\right)$. A pre-additional step was necessary for obtaining the NS and the $\mathrm{NSp} \mathrm{SMZ}_{\mathrm{N}}$, which consists in the washing of the as-synthesized hierarchical zeolite under reflux with a mixture of $100 \mathrm{~mL}$ of hydrochloric acid $(\mathrm{HCl}, 37 \%, 0.2 \mathrm{M})$ purchased from Riedel de Haen and $2 \mathrm{~mL}$ ethanol $(\mathrm{ETOH},>95 \%)$ purchased from Alfa Aesar at $80{ }^{\circ} \mathrm{C}$ during $8 \mathrm{~h}$. This extraction step as described by Choi et al. [39] is necessary to remove the 'dummy' filler: $\mathrm{C}_{22-6-6}$ and the $\mathrm{C}_{18}$ $\mathrm{N}_{3}-\mathrm{C}_{18}$, the molecules that do not contribute in the zeolite structuring. Fig.1 shows a schematic representation of the formation of $\mathrm{SMZ}_{\mathrm{NS}}$ and $\mathrm{SMZ} \mathrm{Z}_{\mathrm{NSp}}$. Proton liquid $\mathrm{NMR}$ tests were done on several samples (in the presence of dioxane as reference and using $\mathrm{D}_{2} \mathrm{O}$ as solvent) after 1 day and 1 week and no leaching of cationic surfactant was observed.
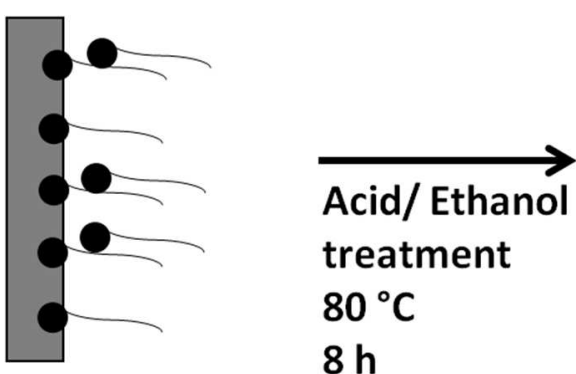

$8 \mathrm{~h}$

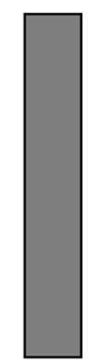

Zeolite external surface
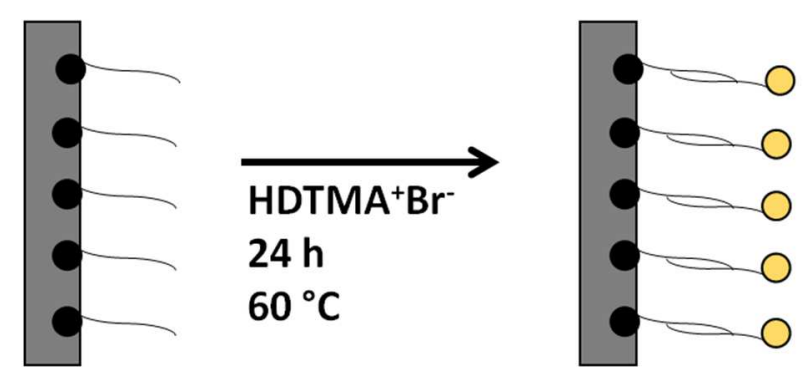

$\mathrm{Br}^{-}$

$\mathrm{C}_{22-6-6}$ or $\mathrm{C}_{18}-\mathrm{N}_{3}-\mathrm{C}_{18}$

HDTMA $^{+}$

Figure 1. Schematic representation of the surface modification of MFI-type NS and NSp in order to obtain the $\mathrm{SMZ}_{\mathrm{NS}}$ and $\mathrm{SMZ} \mathrm{NSp}_{\mathrm{Np}}$ materials. 


\subsection{Nitrate sorption experiments:}

Nitrate removal experiments were carried out by adding a specific amount of the modified zeolite (SMZ materials) to a specific volume of aqueous nitrate solution by using potassium nitrate $\mathrm{KNO}_{3}$ (Fluka) prepared with demineralized water at room temperature. Nitrate solutions with different concentrations [0.8-40.5] mmol. $^{-1}$ were prepared from a 48.4 mmol.L ${ }^{-1}$ mother solution.

First, tests were done in order to verify the effect of $\mathrm{S} / \mathrm{L}$ ratios in $\mathrm{mg} \cdot \mathrm{mL}^{-1}$ (with $\mathrm{S}$ the mass of SMZ and L the volume of nitrate solution) and to determine the optimal $\mathrm{S} / \mathrm{L}$ ratio for nitrate removal. Different masses of SMZ materials were dispersed in $2 \mathrm{~mL}$ of an aqueous potassium nitrate solution at fixed nitrate concentration $\left(19 \mathrm{mmol} . \mathrm{L}^{-1}\right)$ at room temperature with horizontal mechanical shaking in order to reduce powder sedimentation (SMZ).

To study the effect of nitrate concentration, $1 \mathrm{mg}$ of the prepared SMZ were added to $2 \mathrm{~mL}$ of an aqueous nitrate solution with different concentrations placed in small vials. Samples were left at room temperature during $24 \mathrm{~h}$ using a horizontal mechanical shaker.

The effect of contact time was then studied at room temperature by adding in a polypropylene flask $0.5 \mathrm{~g}$ of the SMZ materials to $10 \mathrm{~mL}$ of aqueous nitrate solution with specific concentration. During $24 \mathrm{~h}$ of stirring with a horizontal mechanical shaker, samples were withdrawn at different times with a total uptake that should not exceed 1/10 of the total volume.

Finally, the effect of $\mathrm{pH}$ was carried out by adding $10 \mathrm{mg}$ of the studied material (SMZ) to $20 \mathrm{~mL}$ of a specific concentration of nitrate solution with different $\mathrm{pHs}$ in the range of [4-10]. Samples were left at room temperature during $24 \mathrm{~h}$ using a horizontal mechanical shaker.

For all samples, the solid fractions were removed by filtration using $0.2 \mu \mathrm{m}$ syringe filters, then the supernatants were diluted (100 times) and analyzed using a UV-Visible spectrometer.

The nitrate uptake capacity $Q_{e}$ of each SMZ was calculated as follows (1):

$$
Q_{e}=(L / S) x\left(C_{i}-C_{f}\right)
$$

The percentage of nitrate removal T (\%) or abatement rate was calculated as follows (2):

$$
T \%=\left(C_{i}-C_{f}\right) / C_{i} \times 100,
$$

where $C_{i}$ and $C_{f}$ are the nitrate concentration in the initial and final solution in mmol. $\mathrm{L}^{-1}$, respectively.

The experimental error was calculated and seems to be around $\pm 50, \pm 100$, and \pm 100 mmol. $\mathrm{Kg}^{-1}$ for the $\mathrm{SMZ} \mathrm{Z}_{\mathrm{NS}}, \mathrm{SMZ} \mathrm{Z}_{\mathrm{NSp}}$, and $\mathrm{SMZ} \mathrm{NC}_{\mathrm{NC}}$, respectively.

\section{Results and discussion:}

ZSM-5 zeolites were synthesized in different conditions. Structural and textural properties of the crystals were influenced yet by several parameters: crystallization time, nature of 
structure directing agent, temperature, solid/liquid (solvent) ratio, .... These properties were investigated by different characterization techniques and the most important parameter in our case as shown in the literature [35]: the external surface area was evaluated from $\mathrm{N}_{2}$ adsorption/desorption isotherms.

\subsection{Characterization of the unmodified ZSM-5 zeolites:}

\subsubsection{X-Ray diffraction:}

The purity and the crystallinity of the zeolite samples were analyzed by X-ray diffraction. As shown in Fig. 2, the X-ray diffraction patterns of the four calcined samples: ZSM-5 MC, NC, NS and NSp correspond to the structure of MFI zeolite topology with no impurity observed [42]. The sharpness of the diffraction peaks indicates large crystal size in the case of the ZSM-5 MC. The diffraction peaks of the ZSM-5 NC and NS are less intense and broader, indicating a lower degree of crystallization and smaller crystal sizes due to the synthesis protocol to obtain nanocrystals and the use of the dual-porogenic surfactant $\mathrm{C}_{22-6-6}$ in the case of NS. Only the diffraction peaks corresponding to the planes (h0l) are observed in the XRD pattern of ZSM-5 NS indicating a growth inhibition along the $b$-axis. Very few broad and low intense peaks are observed for ZSM-5 NSp synthesized using the dual-porogenic surfactant $\left(\mathrm{C}_{18}-\mathrm{N}_{3}-\mathrm{C}_{18}\right)$, reflecting a very low degree of crystallization of the zeolitic framework and low dimension of the inorganic framework. In addition, the XRD patterns of the ZSM-5 NS and NSp show a certain degree of mesostructuration revealed by the presence of a broad diffraction peak at low angles $\left(2 \Theta=1.5^{\circ}\right)$ that persists after calcination in the case of ZSM-5 NSp (unlike in the nanosheets) (Fig. 3). This mesostructuration is due to the micellization of $\mathrm{C}_{22-6-6}$ and the $\mathrm{C}_{18}-\mathrm{N}_{3}-\mathrm{C}_{18}$ alkyl chains on the surface of the zeolitic framework that leave a vermiform mesoporosity after removal.

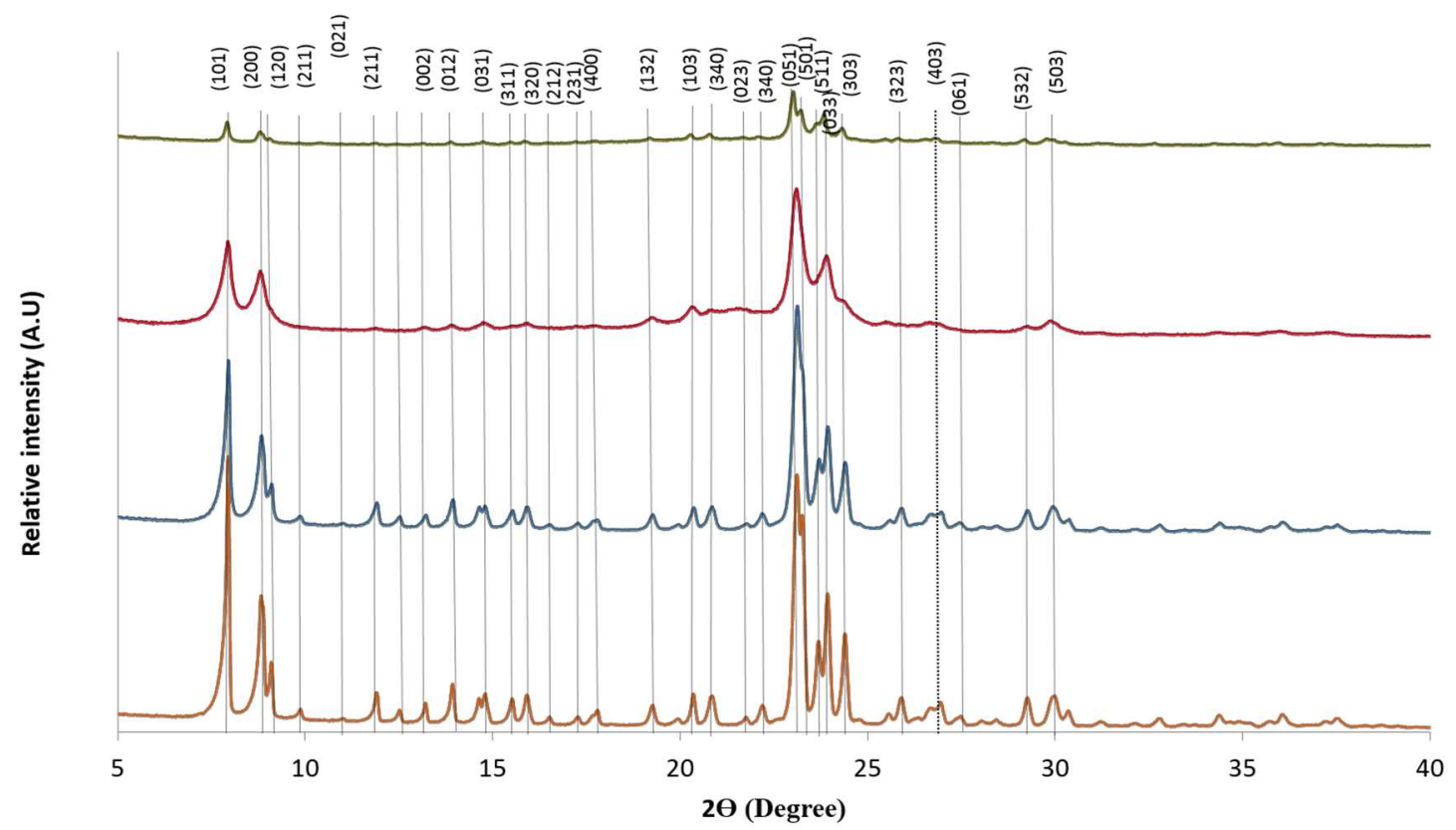

Figure 2. Wide angle X-ray diffraction patterns of the calcined MFI-type zeolite samples (From top to bottom: NSp, NS, NC and MC). 

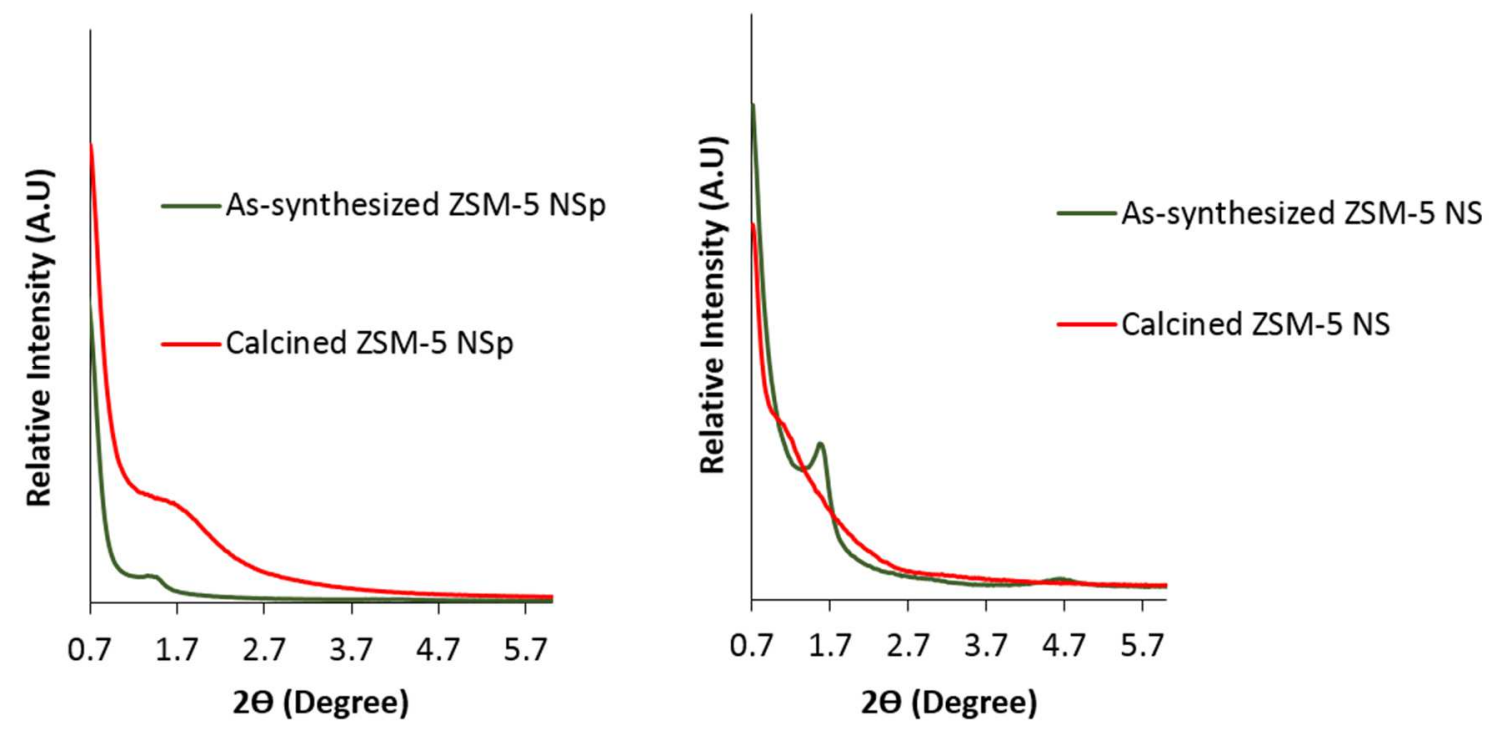

Figure 3. Low angle X-ray diffraction patterns of the calcined MFI-type NSp (left) and the as-synthesized and the calcined MFI-type NS (right) zeolite samples.

\subsubsection{SEM and TEM:}

SEM and TEM images were taken in order to prove the different morphologies and shapes of the four synthesized (calcined) materials (MC, NC, NS, and NSp). A coffin-shaped micrometric crystal of ZSM-5 zeolites with an average size 2-4 $\mu \mathrm{m}$ were observed for MC [37]. In the other hand, NC present aggregates of primary particles of cuboid morphology with smoothie edges and a size of 50-150 nm [38]. TEM images show an inter-crystalline mesoporosity obtained thanks to the agglomeration of these primary particles (Fig. 4A $\mathrm{A}_{1}$ ) which can act in some cases as channels (Fig. 4A2). For NS the formation of ultrathin zeolite layers intergrown in 3-dimentionnal way spaced of $2 \mathrm{~nm}$ with an average thickness of 2.5-3.5 nm (Fig. 4B) is observed [39]. Whereas for NSp a uniform nanocrystals in size and morphology (Fig. 4) with a clearly observed mesoporosity (TEM images) (Fig. 4C) [27].
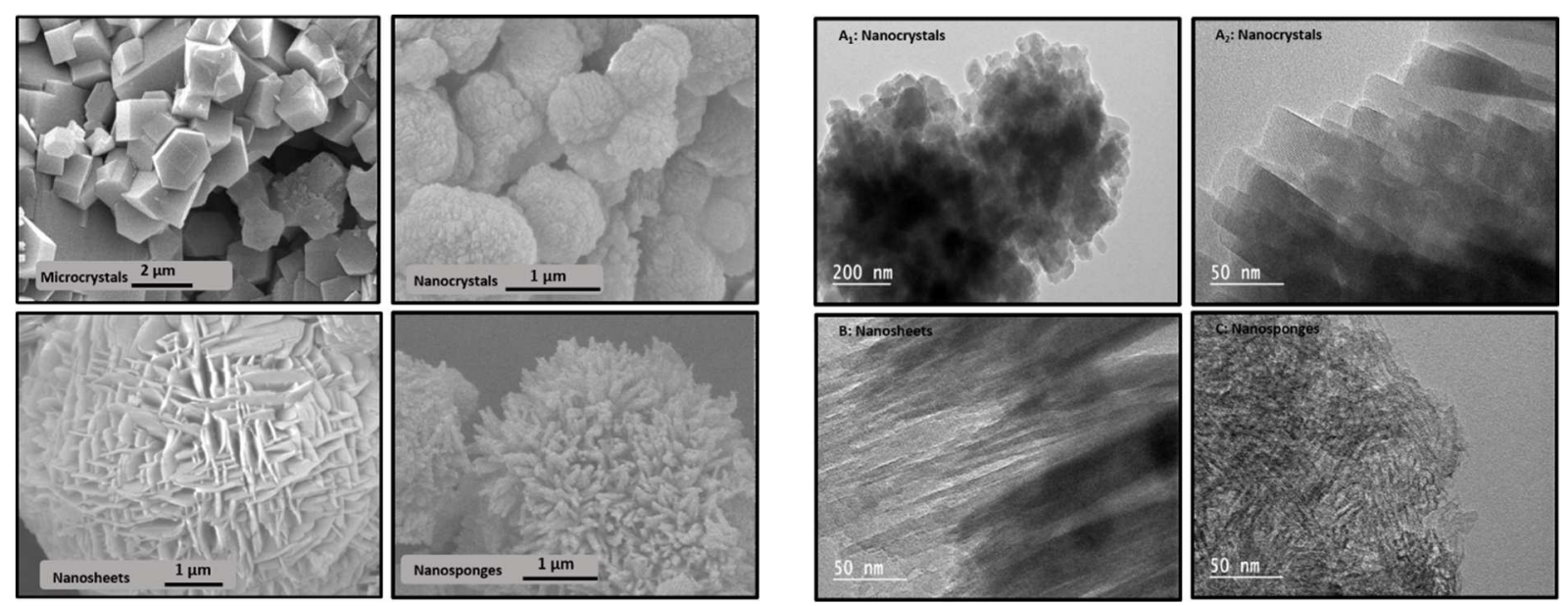
Figure 4. SEM images of the four MFI-type morphologies MC; NC, NS; and NSp and TEM images of the three MFI-type morphologies $\left(\mathrm{A}_{1}\right.$ and $\left.\mathrm{A}_{2}\right)$ : NC; (B): NS; (C): NSp.

\subsection{3 $\mathrm{N}_{2}$ adsorption/ desorption:}

Fig. 5 Shows nitrogen physisorption isotherms of the calcined ZSM-5 MC, NC, NS, and NSp. Table. 1 presents their textural properties (BET surface areas, external surfaces, mico, mesoporous, and porous volumes).

For ZSM-5 MC, a type I adsorption-desorption isotherm was observed corresponding to a microporous material (according to the IUPAC classification) [43]. Whereas, a type Ib and IV adsorption/desorption isotherm were observed for ZSM-5 NC [38] with a hysteresis H3 loop in the relative pressure range $\left(\mathrm{p} / \mathrm{p}_{0}\right)$ of $0.4-1$, which is characteristic of interparticular mesoporosity resulting from the agglomeration of nanocrystals. For ZSM-5 NS, the adsorption isotherm is type I and type II. A hysteresis H3 loop was also observed at relative pressures $>0.4$, which indicates -thanks to its shape- the presence of lamellar materials [39]. For ZSM-5 NSp, the adsorption isotherm is type Ib (micropore filling), type IV (mesopores generated by the $\mathrm{C}_{18}-\mathrm{N}_{3}-\mathrm{C}_{18}$ dual-porogenic surfactant) and type II (interparticular porosity) [27].

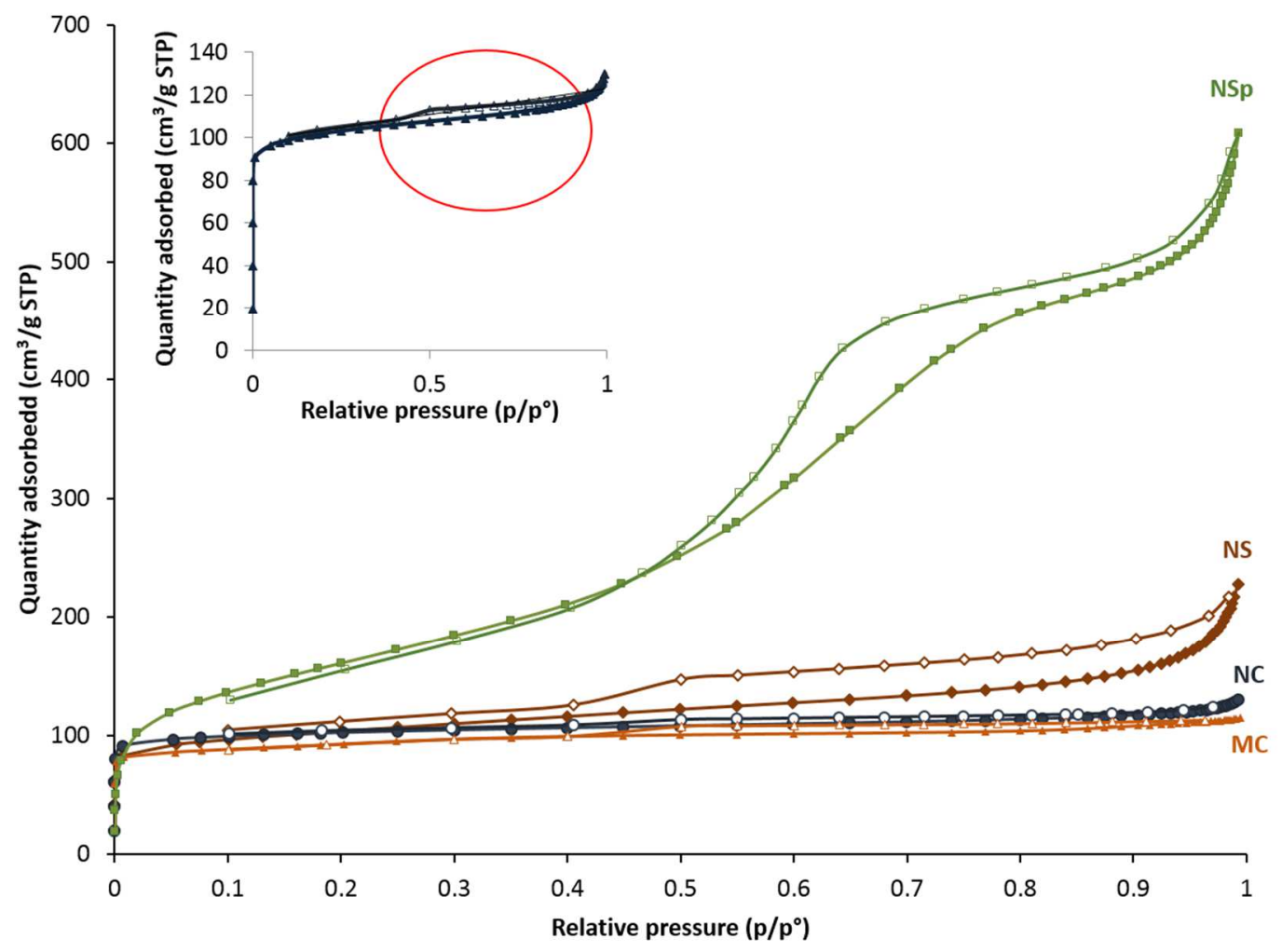



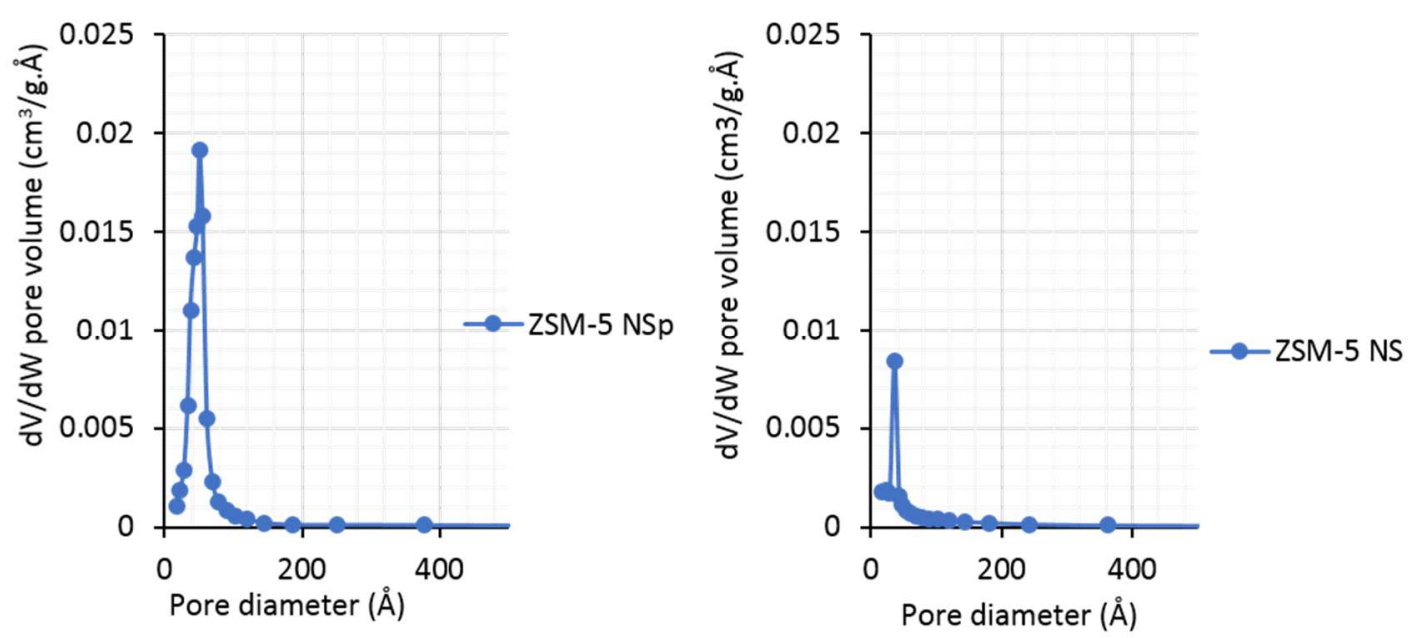

Figure 5. Top : $\mathrm{N}_{2}$ adsorption/desorption isotherms at $77 \mathrm{~K}$ of the calcined MFI-type zeolite MC, NC, NS and NSp (Adsorption branch: filled symbols, Desorption branch: empty symbols); Bottom : BJH pore size distribution of the mesopores for NSp (left) and NS (right).

Decrease of the particle size leads to a pronounced increase of the specific BET surface area $\left(\mathrm{S}_{\mathrm{BET}}\right)$ and the external surface area (Table 1). The external surface area was multiplied by 32 from ZSM-5 MC to ZSM-5 NSp. This raise indicates the formation of an additional porosity as a secondary microporosity in the case of NSp and an additional mesoporosity in the case of $\mathrm{NC}$ (interparticular), NS and NSp as well. The microporous volume $\left(\mathrm{V}_{\text {micro }}\right)$ increases from 0.16 for ZSM-5 MC to $0.2 \mathrm{~cm}^{3} \cdot \mathrm{g}^{-1}$ for the ZSM-5 NSp. As described in our previous paper, the microporous volume for the MFI-type materials was determined by t-plot method. Galarneau et al. [44] described two ways to evaluate the microporous volume; the classical method consists in extrapolating the linear fit in the low-pressure range and taking the intercept as microporous volume; the second one consists in taking the pore volume corresponding to the first point, which starts from the linear regime of the external surface. Concerning the latter zeolite (a hierarchical micro/mesoporous material), the error in microporous volume determination resulting from the classical t-plot analysis can be corrected by using an abacus if the microporous volume to the total pore volume ratio in the solid ( $\mathrm{V}_{\text {micro (t-plot) }} / \mathrm{V}_{\text {tot (t-plot) }} \%$ ) is higher than $20 \%$. In the case of MFI-type NS and NSp, the $\%$ was found lower to $20 \%$ so the abacus could not be applied [35]. The size distribution of the mesopores in the case of NS and NSp was shown monomodale based on the BJH distribution with an average pore size equals to $3.6 \mathrm{~nm}$ and $4.7 \mathrm{~nm}$ for the NS and the NSp, respectively (Fig. 5). The total porous volume was multiplied by 4.6 going from ZSM-5 MC to ZSM-5 NSp.

Table 1. Textural properties of the calcined MFI-type materials.

\begin{tabular}{|c|c|c|c|c|c|c|}
\hline MFI-type & $\begin{array}{c}\text { Microporous } \\
\text { Volume } \\
\left(\mathbf{V}_{\text {micro }}\right)^{\mathrm{a}} \\
\left(\mathrm{cm}^{3} \cdot \mathrm{g}^{-1}\right)\end{array}$ & $\begin{array}{c}\text { Mesoporous } \\
\text { volume } \\
\left(\mathbf{V}_{\text {meso }}\right)^{\mathrm{b}} \\
\left(\mathrm{cm}^{3} \cdot \mathrm{g}^{-1}\right)\end{array}$ & $\begin{array}{c}\text { Total pore } \\
\text { Volume } \\
\left(\mathbf{V}_{\text {tot }}\right)^{\mathrm{c}} \\
\left(\mathrm{cm}^{3} \cdot \mathrm{g}^{-1}\right)\end{array}$ & $\begin{array}{c}\mathbf{S}_{\mathbf{B E T}}{ }^{\mathrm{d}} \\
\left(\mathrm{m}^{2} \cdot \mathrm{g}^{-1}\right)\end{array}$ & $\begin{array}{c}\text { Mesopore } \\
\text { diameter }^{\mathrm{e}} \\
(\mathrm{nm})\end{array}$ & $\begin{array}{c}\text { External } \\
\text { surface } \\
\text { area } \\
\left(\mathrm{m}^{2} \cdot \mathrm{g}^{-1}\right)^{\mathrm{f}}\end{array}$ \\
\hline
\end{tabular}




\begin{tabular}{llccccc} 
Microcrystals & 0.16 & - & 0.16 & 334 & - & 4 \\
Nanocrystals & 0.16 & 0.03 & 0.19 & 383 & - & 50 \\
Nanosheets & 0.16 & 0.18 & 0.34 & 380 & 3.6 & 106 \\
Nanosponges & 0.20 & 0.53 & 0.73 & 566 & 4.7 & 128 \\
\hline
\end{tabular}

${ }^{\text {a }}$ determined by t-plot method

${ }^{b}$ subtraction of the microporous volume from the total porous volume; the mesoporous volume takes account of the mesoporosity induced by the use of the dual porogenic surfactant and interparticular mesoporosity in the case of NS and NSp, and only interparticular mesoporosity in the case of NC.

${ }^{\mathrm{c}}$ determined at the relative pressures $\mathrm{p} / \mathrm{p}^{0}=0.9$

${ }^{\mathrm{d}}$ determined by using BET method

e determined by BJH method applied on the desorption branch of isotherm.

${ }^{f}$ determined by t-plot method: from the linear plot in the range of high thicknesses after condensation for hierarchical materials and by calculation from SEM images for microcrystals and nanocrystals.

\subsection{Characterization of the four surfactant-modified ZSM-5 zeolite materials:}

The quantity of exchangeable ions $\mathrm{Br}^{-}$(as a counter ion of $\mathrm{HDTMA}^{+}$) and $\mathrm{Cl}^{-}$(introduced during the $\mathrm{HCl} / \mathrm{ethanol}$ treatment) over the four surfactant-modified zeolites was determined using X-ray Fluorescence technique. The unit cell molar formula was determined from X-ray Fluorescence results coupled to TG results (Table. 2) As expected, the amount of sorbed $\mathrm{HDTMA}^{+} \mathrm{Br}^{-}$on the surface of these four zeolites increases while decreasing the particle size (increase of the external surface) of the studied $\mathrm{SMZ}$ zeolites: $S M Z_{\mathrm{NSp}}>\mathrm{SMZ} \mathrm{Z}_{\mathrm{NS}}>\mathrm{SMZ}_{\mathrm{NC}}>$

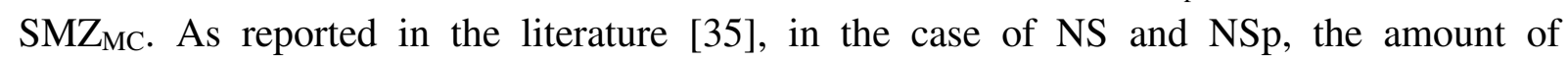
$\mathrm{HDTMA}^{+} \mathrm{Br}^{-}$sorbed on the surface depends on an additional parameter, which is the concentration of the organic species (structure directing agent) with head occluded in the framework and tail pending on the surface illustrated in Fig. 1. As the X-ray fluorescence method is semi-quantitative, the estimated maximum removal capacities calculated referring to $\mathrm{Br}^{-}$and $\mathrm{Cl}^{-}$weight percentages cannot be compared to the experimental values. However, we used the weight percentages to follow the modification success. As shown in Table. 2, the wt.\% of exchangeable anions on $\mathrm{SMZ}_{\mathrm{MC}}$ is low $(0.006 \%)$ which proves that surface modification did not take place on the surface of microcrystals. This value justifies the value of nitrate removal on $\mathrm{SMZ}_{\mathrm{MC}}$ obtained by UV spectrometry analysis. The low external surface of microcrystals can explain the failure of surface modification by $\mathrm{HDTMA}^{+} \mathrm{Br}^{-}$. In order to better follow the surface modification, thermogravimetric analyses (TGA) were also done to the ZSM-5 MC, NC, NS, and NSp. The TGA results were combined with the X-ray Fluorescence results and the unit cell formulas for the SMZ(NS) materials were determined (Table. 2 and Fig. 6). TGA results confirm the failure of $\mathrm{HDTMA}^{+}$surface modification of MC materials since the weight loss $\%$ was found to be $12 \%$ and $13 \%$ before and after surface modification, respectively, which corresponds to the loss of the 4 tetrapropylammonium cations $\left(\mathrm{TPA}^{+}\right.$used as structure-directing agent) that can be present in each ZSM-5 unit cell [45]. Consequently, the results of nitrate adsorption for the MC are not shown and neither discussed. 
Table 2. Unit cell molar formula, Si/Al molar ratio, weight percentage of exchangeable ions $\left(\mathrm{Br}^{-} ; \mathrm{Cl}^{-}\right)$, weight loss and the estimated maximum nitrate removal capacity of the four surfactant-modified ZSM-5 zeolites determined by X-ray fluorescence.

\begin{tabular}{|c|c|c|c|c|}
\hline & $\begin{array}{c}\text { Microcrytals } \\
\text { SMZ }_{M C}\end{array}$ & $\begin{array}{l}\text { Nanocrystals } \\
\text { SMZ }_{N C}\end{array}$ & $\begin{array}{c}\text { Nanosheets } \\
\text { SMZ }_{N C}\end{array}$ & $\begin{array}{c}\text { Nanosponges } \\
\text { SMZ }_{N S}\end{array}$ \\
\hline $\begin{array}{l}\text { Unit cell molar } \\
\text { formula }\end{array}$ & $\begin{array}{c}\left(\mathrm{TPA}^{+}\right)_{4} \mathrm{Na}_{3} \\
\mathrm{Si}_{93} \mathrm{Al}_{3} \mathrm{O}_{192} \\
\left(\mathrm{OH}^{-}\right)_{4}\end{array}$ & $\begin{array}{c}\left(\mathrm{TPA}^{+}\right)_{4} \mathrm{Na}_{2} \mathrm{Si}_{92} \\
\left.\mathrm{Al}_{4} \mathrm{O}_{192}\left(\mathrm{C}_{16}\right)_{0.4}\right)_{0.4} \\
\mathrm{Br}_{0.1}\left(\mathrm{OH}^{-}\right)_{2.3}\end{array}$ & $\begin{array}{l}\left(\mathrm{C}_{22-6-6}{ }^{2+}\right)_{2} \mathrm{Si}_{94} \\
\mathrm{Al}_{2} \mathrm{O}_{192} \\
\left(\mathrm{C}_{16}^{+}\right)_{1.56} \mathrm{Br}_{2.3}^{-} \\
\mathrm{Cl}_{0.46}^{-}\left(\mathrm{OH}^{-}\right)_{0.8}\end{array}$ & $\begin{array}{l}\left(\mathrm{C}_{18} \mathrm{~N}^{+}{ }_{3} \mathrm{C}_{18}\right)_{3.3} \mathrm{Si}_{90} \mathrm{Al}_{6} \\
\mathrm{O}_{192}\left(\mathrm{C}_{16}\right)_{6.5} \mathrm{Br}_{6.9} \mathrm{Cl}_{2} \\
\left(\mathrm{OH}^{-}\right)_{1.4}\end{array}$ \\
\hline $\begin{array}{l}\mathrm{Si} / \mathrm{Al}(\text { molar } \\
\text { ratio) }\end{array}$ & 34 & 21 & 46 & 14 \\
\hline $\begin{array}{c}\text { Wt.\% of } \\
\text { exchangeable } \\
\text { anions }\end{array}$ & $0.006\left(\mathrm{Br}^{-}\right)$ & $0.1\left(\mathrm{Br}^{-}\right)$ & $\begin{array}{c}0.21\left(\mathrm{Cl}^{-}\right) 2.43 \\
\left(\mathrm{Br}^{-}\right)\end{array}$ & $0.65\left(\mathrm{Cl}^{-}\right) 5.06\left(\mathrm{Br}^{-}\right)$ \\
\hline $\begin{array}{l}\text { Weight loss of } \\
\text { organic species } \\
(\%)^{\Phi}\end{array}$ & $12 \%\left(\mathrm{TPA}^{+}\right)$ & $\begin{array}{l}12.7 \%(11 \% \\
\text { TPA }^{+} \text {and } 1.7 \% \\
\left.\text { HDTMA }^{+}\right)\end{array}$ & $\begin{array}{l}20.9 \%(15 \% \\
\mathrm{C}_{22-6-6} \text { and } 5.9 \% \\
\left.\text { HDTMA }^{+}\right)\end{array}$ & $\begin{array}{l}41.4 \%\left(24.4 \% \mathrm{~N}_{6-}\right. \\
\operatorname{Diph}_{\mathrm{e}}{ }^{6+} \text { and } 17 \% \\
\left.\mathrm{HDTMA}^{+}\right)\end{array}$ \\
\hline
\end{tabular}

${ }^{\bullet} \mathrm{C}_{16}{ }^{+}$represents HDTMA ${ }^{+}$cation.

$\phi$ Determined from TGA results.

For the ZSM-5 NC, thermogravimetric curve showed $13.5 \%$ of weight loss in the range of $100-800{ }^{\circ} \mathrm{C}$ attributed to the loss of the $\mathrm{TPA}^{+}$ions (total organic loss) (11.5 wt.\%) used during synthesis and physisorbed water molecules $(2 \mathrm{wt} . \%)$. The percentage of total organic loss increases from $11.5 \%$ to $12.7 \%$ after surface modification indicating the loss of HDTMA ${ }^{+}$ molecules $\left(1.7\right.$ wt.\%) double linked to the surface of SMZ $\mathrm{NC}_{\mathrm{NC}}$ materials. For the raw ZSM-5 NS and NSp, an organic content of $28 \%$ and $51 \%$ was observed (Fig. 6) which refers to the loss of the dual porogenic surfactants $\mathrm{C}_{22-6-6}$ and $\mathrm{C}_{18}-\mathrm{N}_{3}-\mathrm{C}_{18}$ entrapped in the micropores of the ZSM-5 NS and NSp unit cell, respectively. The excess amounts of the extra-framework dual-porogenic surfactants (dummy filler) were removed by $\mathrm{HCl} / \mathrm{ETOH}$ treatment, as shown in Fig. 6, where the amount of organic dropped from $28 \%$ to $16.4 \%$ and from $51 \%$ to $32 \%$ for the ZSM-5 NS and NSp, respectively. After surface modification of the treated nanomaterials with $\mathrm{HDTMA}^{+} \mathrm{Br}^{-}$, the percentages of weight loss increase to reach $20.9 \%$ for the $S M Z_{N S}$ and $41.4 \%$ for the $S M Z_{N S p}$. These results prove the success of surface modification with $\mathrm{HDTMA}^{+} \mathrm{Br}^{-}$in the following order $\mathrm{SMZ}_{\mathrm{NSp}}>\mathrm{SMZ}_{\mathrm{NS}}>\mathrm{SMZ}_{\mathrm{NC}}$. 

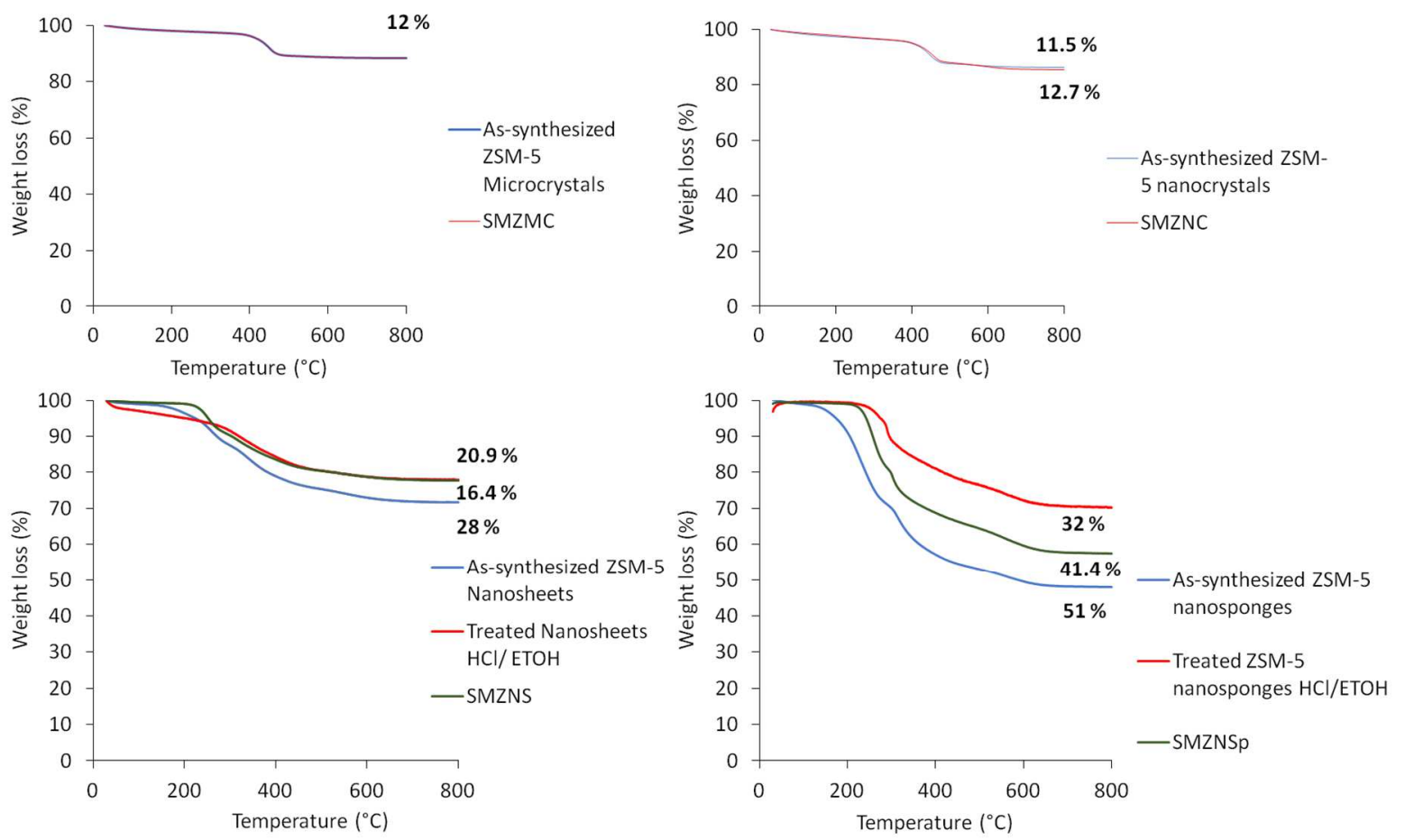

Figure 6. Thermal analysis curves of the as-synthesized MFI-type NC, NS and NSp before and after $\mathrm{HDTMA}^{+} \mathrm{Br}^{-}$surface modification. Percentages correspond to the weight losses in the $100-800^{\circ} \mathrm{C}$ range associated to the decomposition of the organic matter

\subsection{Nitrate removal tests:}

\subsubsection{Effect of S/L ratio:}

In order to determine the optimal $\mathrm{S} / \mathrm{L}$ ratio (expressed in $\mathrm{mg} \cdot \mathrm{mL}^{-1}$ ), different amounts of $\mathrm{SMZ}_{\mathrm{NC}}, \mathrm{SMZ}_{\mathrm{NS}}$, and SMZ $\mathrm{NSp}$ were added to a $2 \mathrm{~mL}$ nitrate solution $\left(19 \mathrm{mmol} . \mathrm{L}^{-1}\right)$ and were maintained for $24 \mathrm{~h}$ at room temperature with a mechanical horizontal shaking. The capacity and the abatement rate $(\%)$ of nitrate removed after $24 \mathrm{~h}$ are reported in Fig. 7. The same tendency was observed for the three materials when decreasing the S/L ratio: the nitrate removal capacity (inversely proportional to the abatement rate \%) increases when passing from high to low S/L ratios $810( \pm 50), 1941( \pm 100), 2125( \pm 100) \mathrm{mmol} . \mathrm{Kg}^{-1}$ in the case of $\mathrm{S} / \mathrm{L}$ ratio $=0.5 \mathrm{mg} \cdot \mathrm{mL}^{-1}$, for the $\mathrm{SMZ} \mathrm{NC}_{\mathrm{NC}}, \mathrm{SMZ}_{\mathrm{NS}}$ and $\mathrm{SMZ} \mathrm{Z}_{\mathrm{NSp}}$, respectively. The highest nitrate removal capacity was observed to be $2125 \mathrm{mmol} . \mathrm{Kg}^{-1}$ in the case of the $\mathrm{SMZ}_{\mathrm{NSp}}$, the material which highly succeed through surface $\mathrm{HDTMA}^{+} \mathrm{Br}^{-}$modification (material having initially, before surface modification, the highest external surface area as shown before). This optimal $\mathrm{S} / \mathrm{L}$ ratio of $0.5 \mathrm{mg} . \mathrm{mL}^{-1}$ was used in the following nitrate removal experiments (effect of initial nitrate concentration, contact time, and $\mathrm{pH}$ ). It is noteworthy that for the modified ZSM-5 nanosheets SMZ $\mathrm{N}_{\mathrm{NS}}$, the same experiments were reported in the literature by fixing the $\mathrm{S} / \mathrm{L}$ ratio at $20 \mathrm{mg} \cdot \mathrm{mL}^{-1}$ that is why the maximum removal capacity was underestimated [34]. 


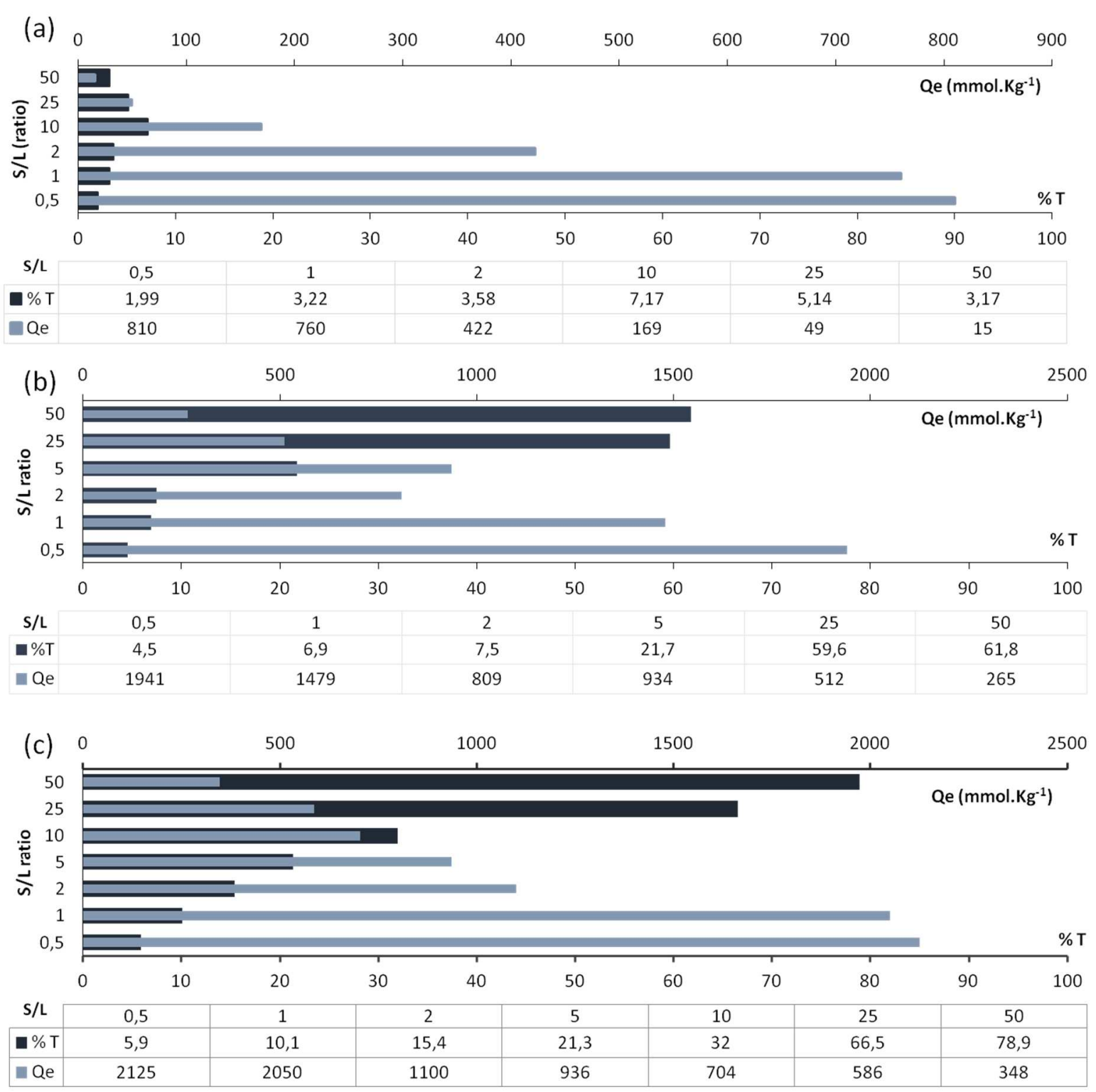

Figure 7. Histograms of maximum removal capacity $\left(\mathrm{Q}_{\mathrm{e}}\right)$ (in blue) and abatement rate (T \%) (in black) with different $\mathrm{S} / \mathrm{L}$ ratios at initial nitrate concentration equal to $19 \mathrm{mmol}^{-1}($ at $\mathrm{pH}=6)$ on $\mathrm{SMZ}_{\mathrm{NC}}(\mathrm{a}), \mathrm{SMZ}_{\mathrm{NS}}(\mathrm{b})$, and $\mathrm{SMZ}_{\mathrm{NSp}}(\mathrm{c})$.

\subsubsection{Effect of nitrate concentration:}

The rate of nitrate removal for the three studied materials was investigated at different initial concentrations by varying the nitrate concentration from 0.8 to $40.5 \mathrm{mmol} . \mathrm{L}^{-1}$, with a fixed $\mathrm{S} / \mathrm{L}$ ratio equal to $0.5 \mathrm{mg} \cdot \mathrm{mL}^{-1}$ (optimal $\mathrm{S} / \mathrm{L}$ ratio found before), at $\mathrm{pH}$ of 6 After $24 \mathrm{~h}$ of mechanical horizontal shaking, the isotherms were drawn (Fig 8). The nitrate removal capacity $Q_{e}$ increases progressively with the increase of the nitrate initial concentration till reaching a plateau proving a saturation of external modified material surfaces (equilibrium) 
for a nitrate concentration equal to $19 \mathrm{mmol} . \mathrm{L}^{-1}$ with a maximum removal capacities equal to $810( \pm 50), 1941( \pm 100), 2125( \pm 100) m_{m o l} \mathrm{Kg}^{-1}$ in the case of SMZ $\mathrm{NC}_{\mathrm{NC}}, \mathrm{SMZ} \mathrm{Z}_{\mathrm{NS}}$, and $\mathrm{SMZ}_{\mathrm{NSp}}$, respectively. As shown in the inset of Fig. 8, at low concentrations, the three modified materials $S M Z_{N C}, S M Z_{N S}$, and $\mathrm{SMZ}_{\mathrm{NSp}}$ showed a high relative removal capacity for nitrate decontamination.

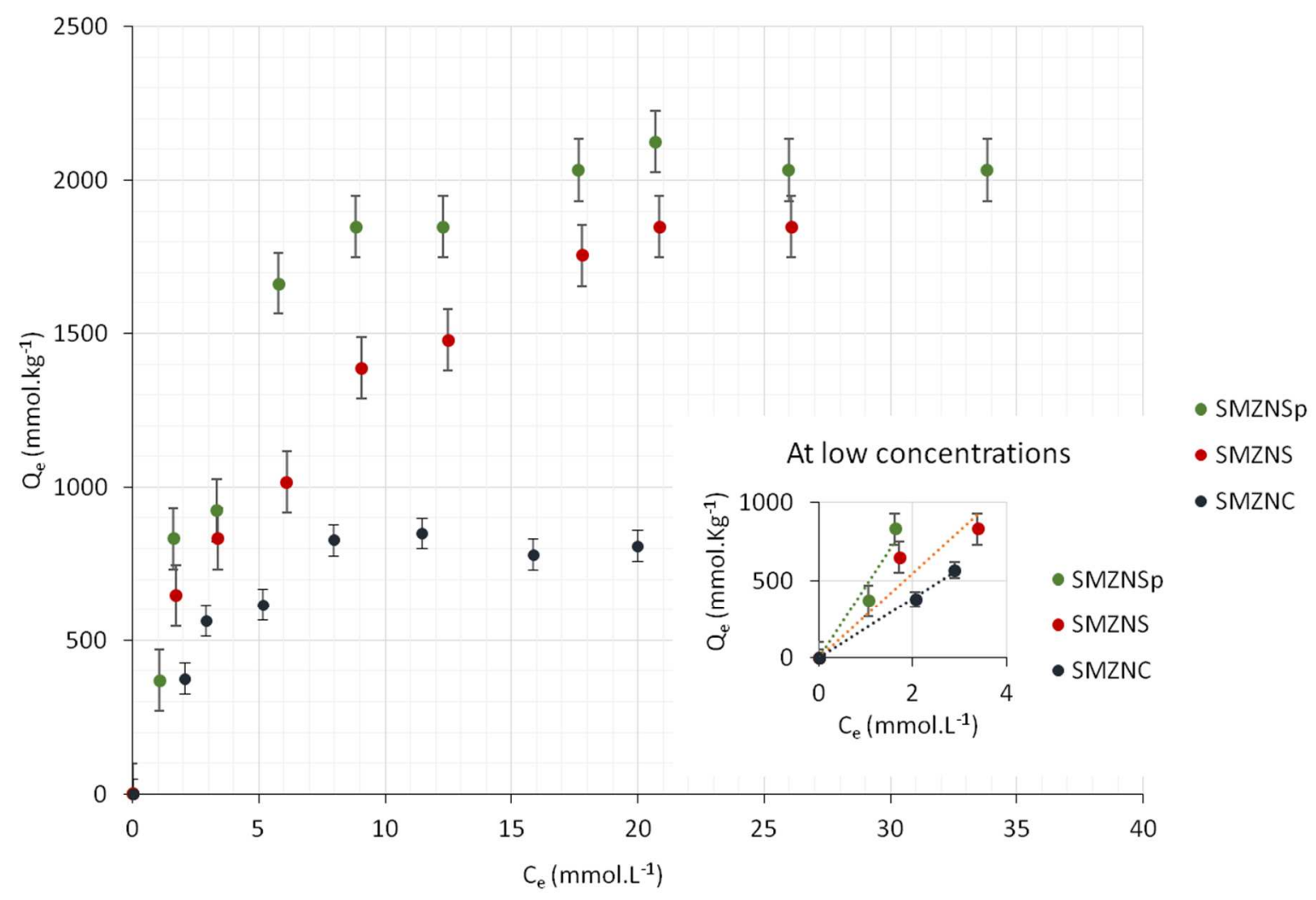

Figure 8. Nitrate adsorption isotherm $\left(\right.$ at $\mathrm{pH}=6$ ) on $\mathrm{SMZ}_{\mathrm{NSp}}, \mathrm{SMZ}_{\mathrm{NS}}$, and $\mathrm{SMZ}_{\mathrm{NC}}$ with $\mathrm{S} / \mathrm{L}$ ratio equal to $0.5 \mathrm{mg} \cdot \mathrm{mL}^{-1}$ in the nitrate concentration range $[0.8-40.5] \mathrm{mmol} \cdot \mathrm{L}^{-1}$. Inset : at low concentrations.

In order to get better insight of the adsorption mechanism, the Langmuir, Freundlich, and Dubinin-Radushkevich adsorption models were applied to the nitrate adsorption isotherms of $S M Z_{N C}, S M Z_{N S}$, and $S M Z_{N S p}$ materials [46-48]. The best correlation was found with the Langmuir adsorption model with linear regression coefficients equal to 0.982, 0.961, and 0.982, respectively Fig. 9. Langmuir adsorption equation is extensively used for the adsorption of molecules and ions (organic or inorganic) from a liquid medium. It assumes that the maximum adsorption corresponds to a saturated monolayer of the sorbed molecules on the surface of the adsorbent (which is structurally and energetically homogeneous) and considering: 1) the adsorption is done with no lateral interaction between the sorbed molecules, and 2) the sorbent has a finite capacity for the adsorbate [47].

The linear form of Langmuir adsorption model is represented as follows (3):

$$
Q_{e} / Q_{\max }=\left(\begin{array}{lll}
\boldsymbol{k} & \left.C_{e}\right) /\left(1+k x C_{e}\right)
\end{array}\right.
$$


where, $\mathrm{Q}_{\mathrm{e}}$ and $\mathrm{Q}_{\max }$ are described before. $\mathrm{C}_{\mathrm{e}}$ and $\mathrm{k}$ are the equilibrium nitrate concentration in the solution in mmol. $\mathrm{L}^{-1}$ and the Langmuir constant in $\mathrm{L}_{\mathrm{Kg}} \mathrm{Kg}^{-1}$, respectively.

Fig. 9 shows the linearization of nitrate removal isotherms for the three modified materials $\left(\mathrm{SMZ}_{\mathrm{NC}}, \mathrm{SMZ}_{\mathrm{NS}}\right.$, and $\mathrm{SMZ} \mathrm{Z}_{\mathrm{NSp}}$ ) using Langmuir model. By developing the equation (3), we obtain another linear equation represented as follows (4):

$$
C_{e} / Q_{e}=\left(1 /\left(k x Q_{\max }\right)\right)+\left(C_{e} / Q_{\max }\right)
$$

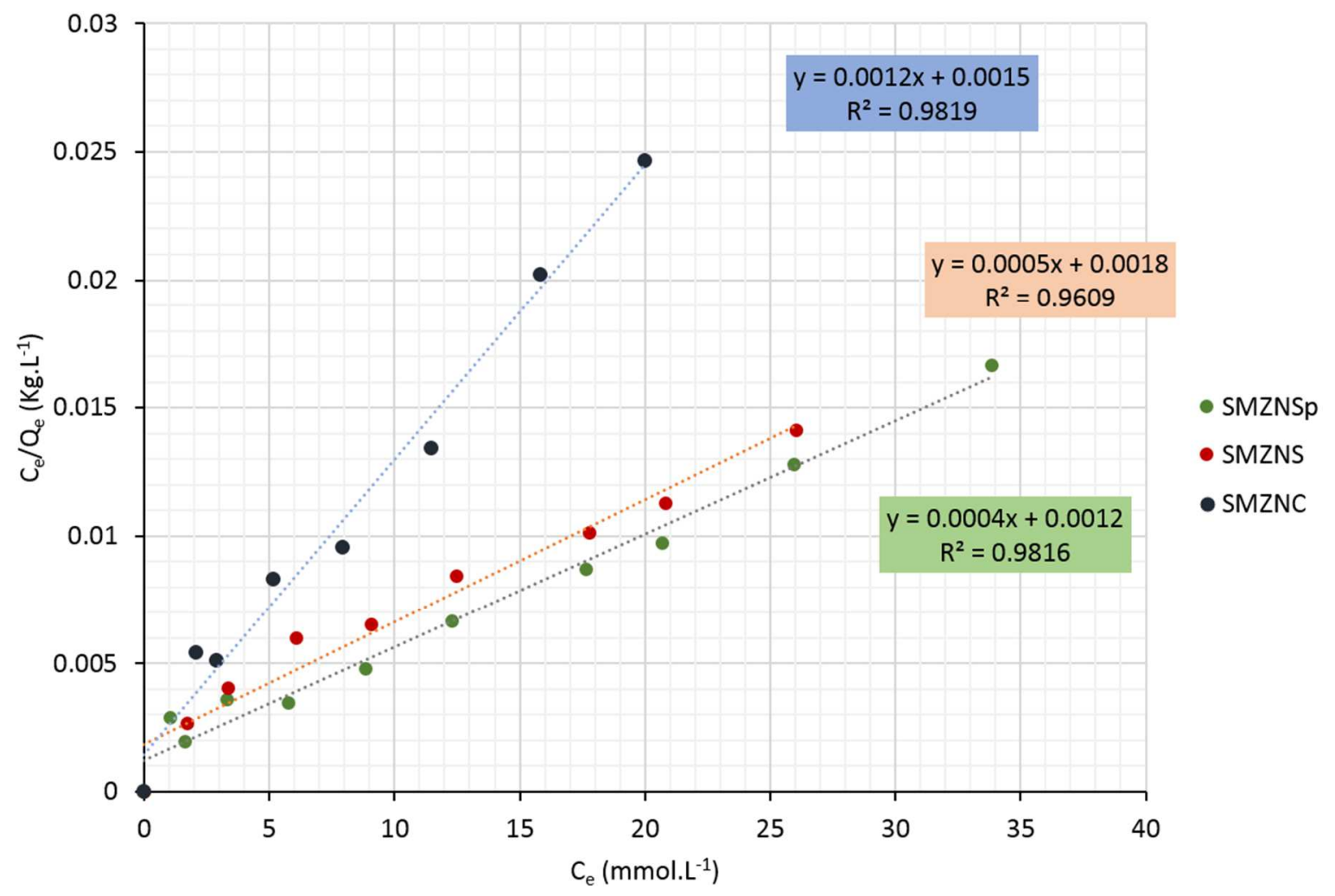

Figure 9. Linearization of nitrate adsorption on $\mathrm{SMZ}_{\mathrm{NC}}, \mathrm{SMZ}_{\mathrm{NS}}$, and $\mathrm{SMZ}_{\mathrm{NSp}}$ by Langmuir model.

Dubinin-Radushkevich (D-R) isotherm model was also used in order to determine the nature of the interaction (adsorption mechanism) between nitrate ions and $\mathrm{SMZ} \mathrm{Z}_{\mathrm{NC}}, \mathrm{SMZ} \mathrm{Z}_{\mathrm{NS}}$ or $\mathrm{SMZ}_{\mathrm{NSp}}$ materials and evaluate the mean adsorption free energy over SMZ materials. D-R equation is as follows (5) [48]:

$$
\operatorname{Ln} Q_{e}=\operatorname{Ln} Q_{\max }-K_{D-R} \varepsilon^{2}
$$

Where $\mathrm{Q}_{\mathrm{e}}$ is the amount nitrate removal by SMZ material in mol.g ${ }^{-1}$; $\mathrm{Q}_{\max }$ is the maximum theoretical nitrate removal capacity in mol.g ${ }^{-1} ; \mathrm{K}_{\mathrm{D}-\mathrm{R}}$ is the isotherm constant related to the nitrate adsorption energy $\left(\mathrm{mol}^{-1} \mathrm{~K}^{-1} \mathrm{~J}^{-1}\right) ; \varepsilon$ is the Polany potential which is equal to RT $\ln$ $\left(1+1 / \mathrm{C}_{\mathrm{e}}\right)$ with $\mathrm{R}$ and $\mathrm{T}$ the gas constant $\left(\mathrm{kJ} \mathrm{mol}^{-1} \mathrm{~K}^{-1}\right)$ and the temperature $(\mathrm{K})$, respectively. $\mathrm{C}_{\mathrm{e}}$ is the equilibrium concentration of nitrate in mol. $\mathrm{L}^{-1}$.

The correlation coefficients shown in Fig. 10 indicate an agreement of the experimental data with the D-R isotherm model. In addition, the mean free energy of the adsorption mechanism 
$\left(\mathrm{E}\right.$ in $\mathrm{kJ} \mathrm{mol}^{-1}$ ), which represents the free energy when one mole of nitrate in the solution moves from infinity to reach the adsorption surface, can be obtained using the following relation (6):

$$
E=\left(2 K_{D-R}\right)^{-0.5}
$$

The value of the free energy, as known, is very important to predict the type of adsorption mechanism. The adsorption can be considered as physical adsorption if the E value is below 8 $\mathrm{kJ} \mathrm{mol}^{-1}$. It is considered to be as ion exchange mechanism if this value is between 8 and 16 $\mathrm{kJ} \mathrm{mol}^{-1}$. These values were found to be $\sim 11.2,8.5$, and $8.5 \mathrm{~kJ} \mathrm{~mol}^{-1}$ for $\mathrm{SMZ}_{\mathrm{NC}}, \mathrm{SMZ}_{\mathrm{NS}}$, and $\mathrm{SMZ}_{\mathrm{NSp}}$, respectively, indicating that the adsorption on $\mathrm{SMZ}_{\mathrm{NC}}, \mathrm{SMZ} \mathrm{Z}_{\mathrm{NS}}$, and $\mathrm{SMZ}_{\mathrm{NSp}}$ is governed as expected by ion exchange.

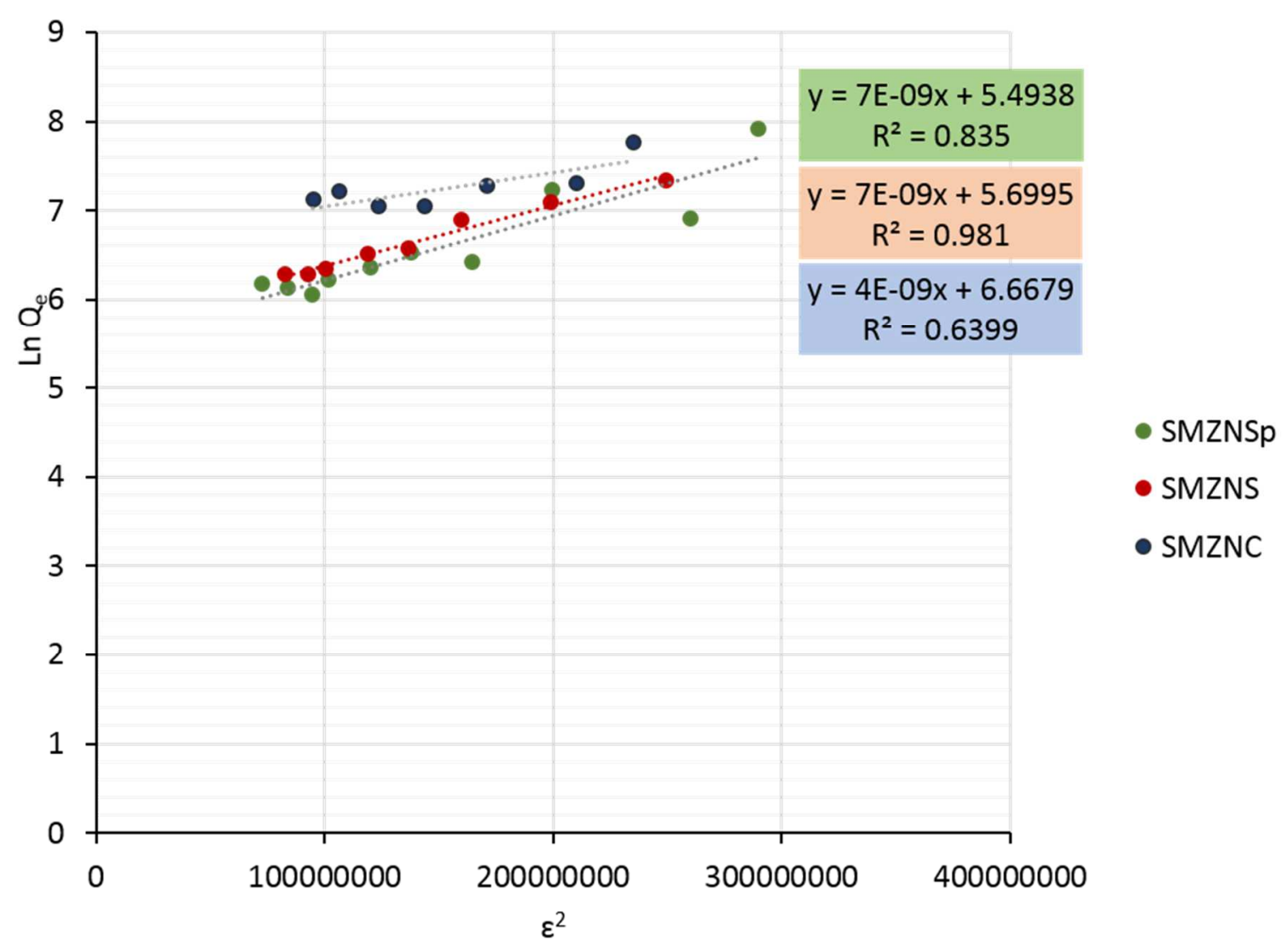

Figure 10. Linearization of nitrate adsorption on $\mathrm{SMZ}_{\mathrm{NC}}, \mathrm{SMZ}_{\mathrm{NS}}$, and $\mathrm{SMZ} \mathrm{Z}_{\mathrm{NSp}}$ using DubininRedushkevish model.

\subsubsection{Effect of contact time:}

The nitrate uptake rate has been evaluated and optimized for the three modified materials at pH 6 for an initial nitrate concentration equal to 19 mmol. $\mathrm{L}^{-1}$ with a fixed S/L ratio 0.5 mg. $\mathrm{mL}^{-1}$. The kinetics were then simulated by different adsorption models: the pseudo-firstorder and the pseudo-second-order in order to better describe the experimental results. Fig. 11 
shows an ultra-fast nitrate removal on the three modified zeolite materials. 5.3, 4.1, and $2.5 \%$ from the total initial nitrate molecules are removed on $\mathrm{SMZ} Z_{\mathrm{NSp}}, \mathrm{SMZ} \mathrm{Z}_{\mathrm{NS}}$, and $\mathrm{SMZ}_{\mathrm{NC}}$, respectively within the first 2 min of contact time before reaching the equilibrium. Maximum removal capacities have been determined to be $810( \pm 50), 1941( \pm 100), 2125( \pm 100)$ mmol. $\mathrm{Kg}^{-1}$ for the $\mathrm{SMZ}_{\mathrm{NC}}, \mathrm{SMZ}_{\mathrm{NS}}$, and $\mathrm{SMZ} \mathrm{Z}_{\mathrm{NSp}}$, respectively. The inversely proportional relation between the abatement rate \% (\% nitrate removal) and the nitrate removal capacity $\left(\mathrm{Q}_{\mathrm{e}}\right)$ has to be taken into consideration. Therefore, the optimal conditions referring to the highest $\mathrm{Q}_{\mathrm{e}}$ and not the highest nitrate removal \% (highest S/L ratio) were chosen.

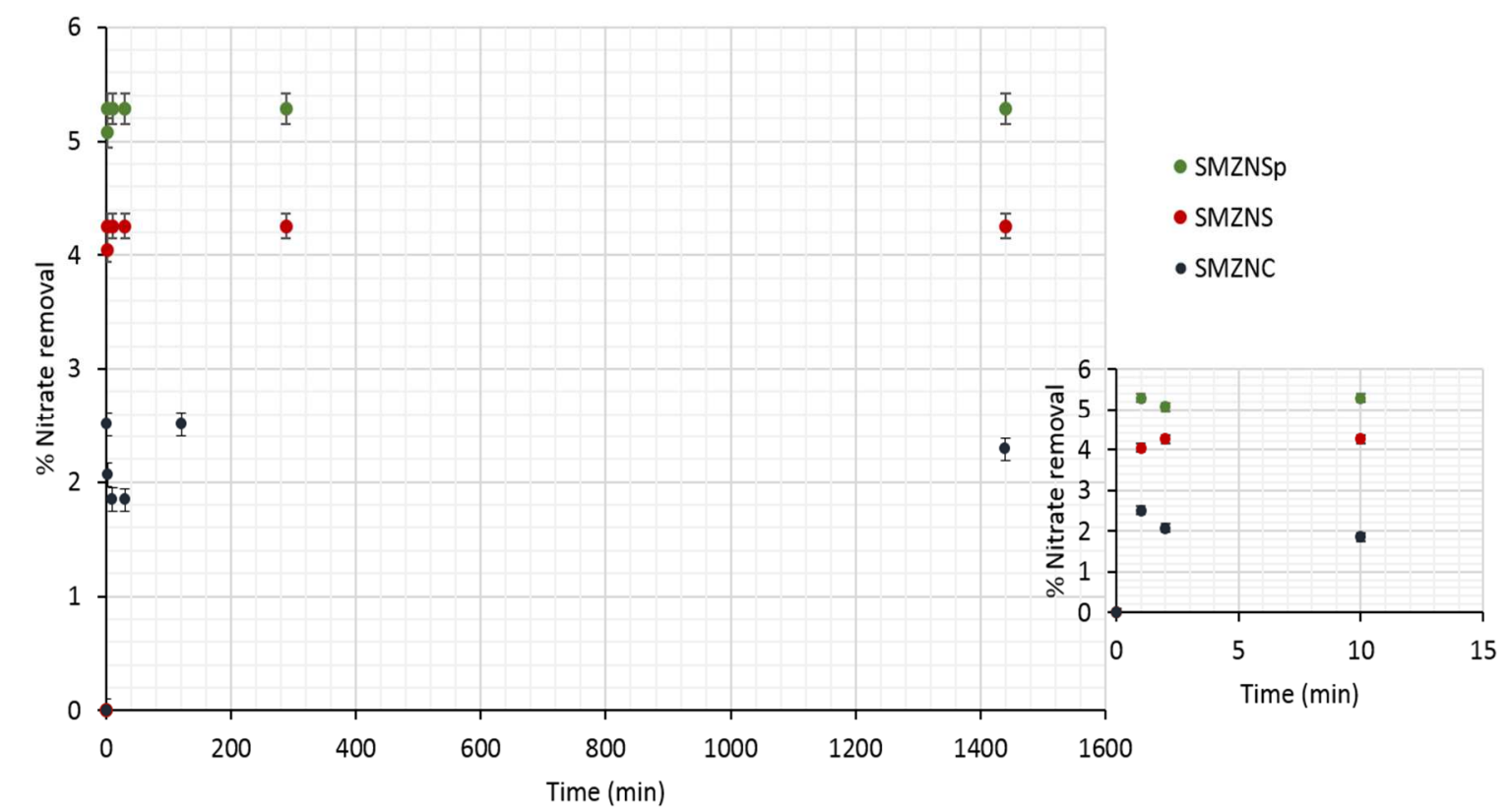

Figure 11. Kinetic curves of nitrate removal (at $\mathrm{pH}=6$ ) on $\mathrm{SMZ}_{\mathrm{NC}}, \mathrm{SMZ}_{\mathrm{NS}}$, and $\mathrm{SMZ}_{\mathrm{NSp}}$ with a $\mathrm{S} / \mathrm{L}$ ratio of $0.5 \mathrm{mg} \cdot \mathrm{mL}^{-1}$. Insert: at short time.

The pseudo-second-order model was described in the literature as the pseudo-first-order model: where a saturated monolayer of adsorbates occurs on specific sites on the surface of the material without any interaction between sorbed ions [49,50]. However, in our case the nitrate uptake on the modified zeolite surfaces is governed by a second-order rate equation [49].

The linearization of the pseudo-second-order is as follows (7):

$$
T / Q_{T}=\left(T / Q_{e}\right)+1 /\left(k_{2} \times Q_{e}^{2}\right),
$$

where, $\mathrm{Q}$ is the removal capacity and k'2 is the pseudo-second-order constant in $\mathrm{Kg}^{\prime} \mathrm{mmol}^{-}$ ${ }^{1} \cdot \mathrm{min}^{-1}$.

The plots of $\mathrm{T} / \mathrm{Q}_{\mathrm{T}}$ versus $\mathrm{T}$ for $\mathrm{SMZ} \mathrm{Z}_{\mathrm{NSp}}, \mathrm{SMZ} \mathrm{Z}_{\mathrm{NS}}$ and $\mathrm{SMZ} \mathrm{Z}_{\mathrm{NC}}$ are shown in Fig. 12. The results show that $\mathrm{SMZ}_{\mathrm{NSp}}, \mathrm{SMZ} \mathrm{Z}_{\mathrm{NS}}$, and $\mathrm{SMZ} \mathrm{Z}_{\mathrm{NC}}$ fitted the pseudo second-order adsorption model in the nitrate removal with $\mathrm{R}^{2}$ correlation coefficients close to 1 . The rate constant and the maximum adsorption capacity were calculated graphically and were listed in Table. 3. Q $\max$ estimated from the plot are close to the experimental $\mathrm{Q}_{\max }$. 


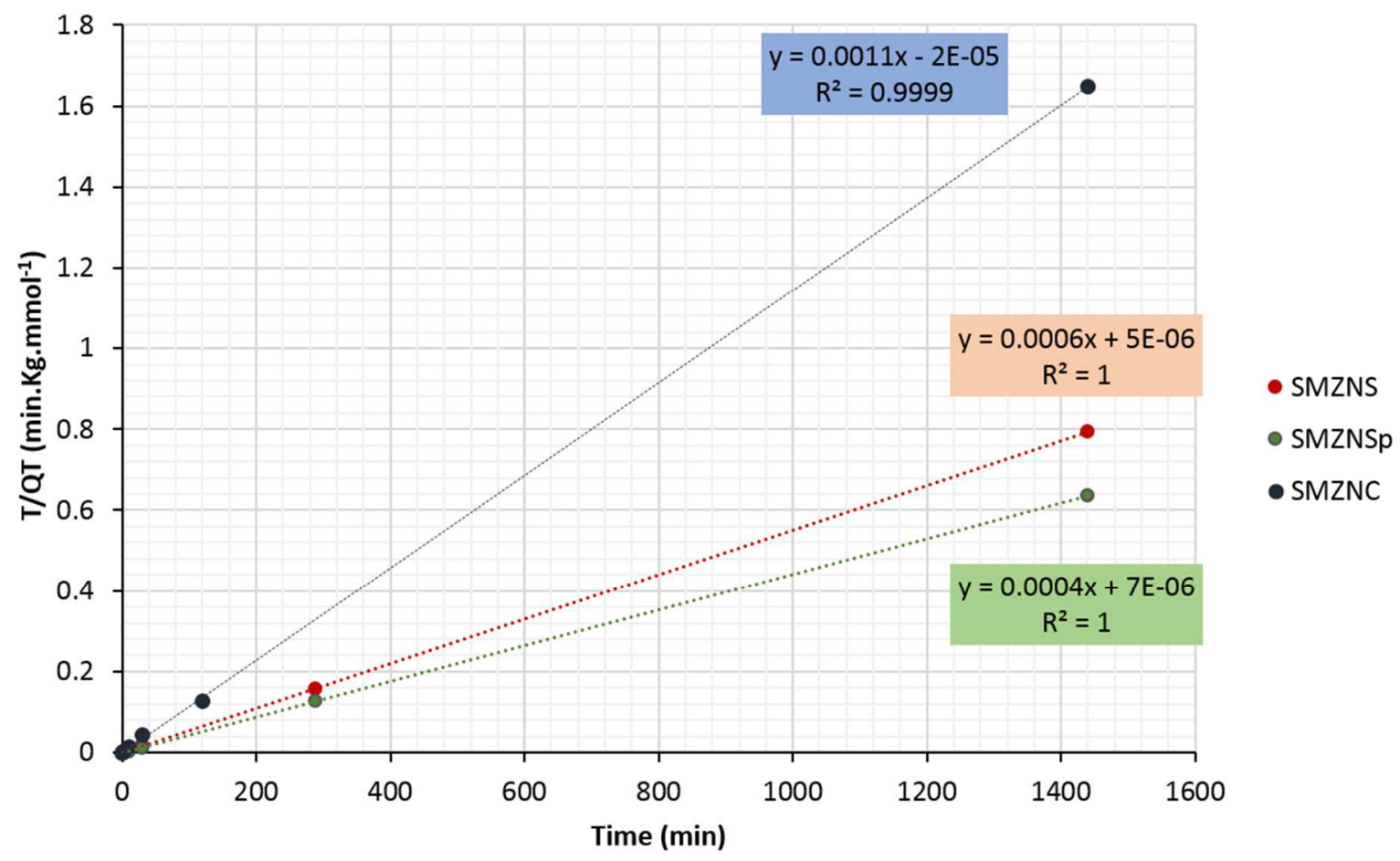

Figure 12. Linearization of nitrate removal kinetic curve on $S M Z_{N C}, S M Z_{N S}$, and $S M Z_{N S p}$ by pseudosecond order model.

Table 3. kinetic parameters of the $\mathrm{SMZ}_{\mathrm{NSp}}$, $\mathrm{SMZ}_{\mathrm{NS}}$, and $\mathrm{SMZ}_{\mathrm{NC}}$ materials.

\begin{tabular}{|c|c|c|c|c|c|c|c|c|c|}
\hline Materials & \multicolumn{3}{|c|}{$\underline{S M Z_{N S p}}$} & \multicolumn{3}{|c|}{$\underline{S M Z_{N S}}$} & \multicolumn{3}{|c|}{$\underline{S M Z_{N C}}$} \\
\hline Model & $\mathrm{R}^{2}$ & $\mathrm{k}_{2}^{\prime}$ & $\mathrm{Q}_{\max }$ & $\mathrm{R}^{2}$ & $\mathrm{k}_{2}^{\prime}$ & $\mathrm{Q}_{\max }$ & $\mathrm{R}^{2}$ & $\mathrm{k}_{2}^{\prime}$ & $\mathrm{Q}_{\max }$ \\
\hline$\frac{\text { Pseudo-second- }}{\text { order }}$ & 1 & $1.12 * 10^{-12}$ & 2500 & 1 & $1.8^{*} 10^{-12}$ & 1666 & 0.9999 & $6.1 * 10^{-9}$ & 910 \\
\hline
\end{tabular}

\subsubsection{Effect of pH:}

The effect of $\mathrm{pH}$ on nitrate removal capacity over SMZ materials was carried out by testing the adsorption at different $\mathrm{pH}$ values in the range of 4-10. The optimal $\mathrm{pH}$ value was determined then after drawing the histograms. The results shown in Fig. 13 prove a $\mathrm{pH}$ dependent nitrate adsorption with a maximum nitrate removal capacity at $\mathrm{pH}=6$ for the three modified materials: $810( \pm 50), 1941( \pm 100), 2125( \pm 100) \mathrm{mmol} \cdot \mathrm{Kg}^{-1}$. At low $\mathrm{pH}$, in the range of 4-6, when moving to an acidic medium region, nitrate removal capacity presents a slight decrease and this could be explained by the increase of the $\mathrm{H}_{3} \mathrm{O}^{+}$concentration that may lead to the formation of another form of nitrate which is the $\mathrm{HNO}_{3}$ form, that could limit the surface exchange between $\mathrm{Br}^{-}$and $\mathrm{Cl}^{-}$species and $\mathrm{NO}_{3}{ }^{-}$. In addition, a slight decrease in the nitrate removal capacity was also noticed once being in the basic medium range. This could be explained by the presence of $\mathrm{OH}^{-}$species in such medium and its competition with $\mathrm{NO}_{3}^{-}$in contaminated water. As we can see optimal $\mathrm{pH}$ was found to be at $\mathrm{pH}=6$, the one used for all 
the previous tests. These results show that the maximum removal capacities obtained before are the highest that could be obtained over $\mathrm{SMZ}_{\mathrm{NC}}, \mathrm{SMZ}_{\mathrm{NS}}$, and $\mathrm{SMZ} \mathrm{Z}_{\mathrm{NSp}}$ materials.

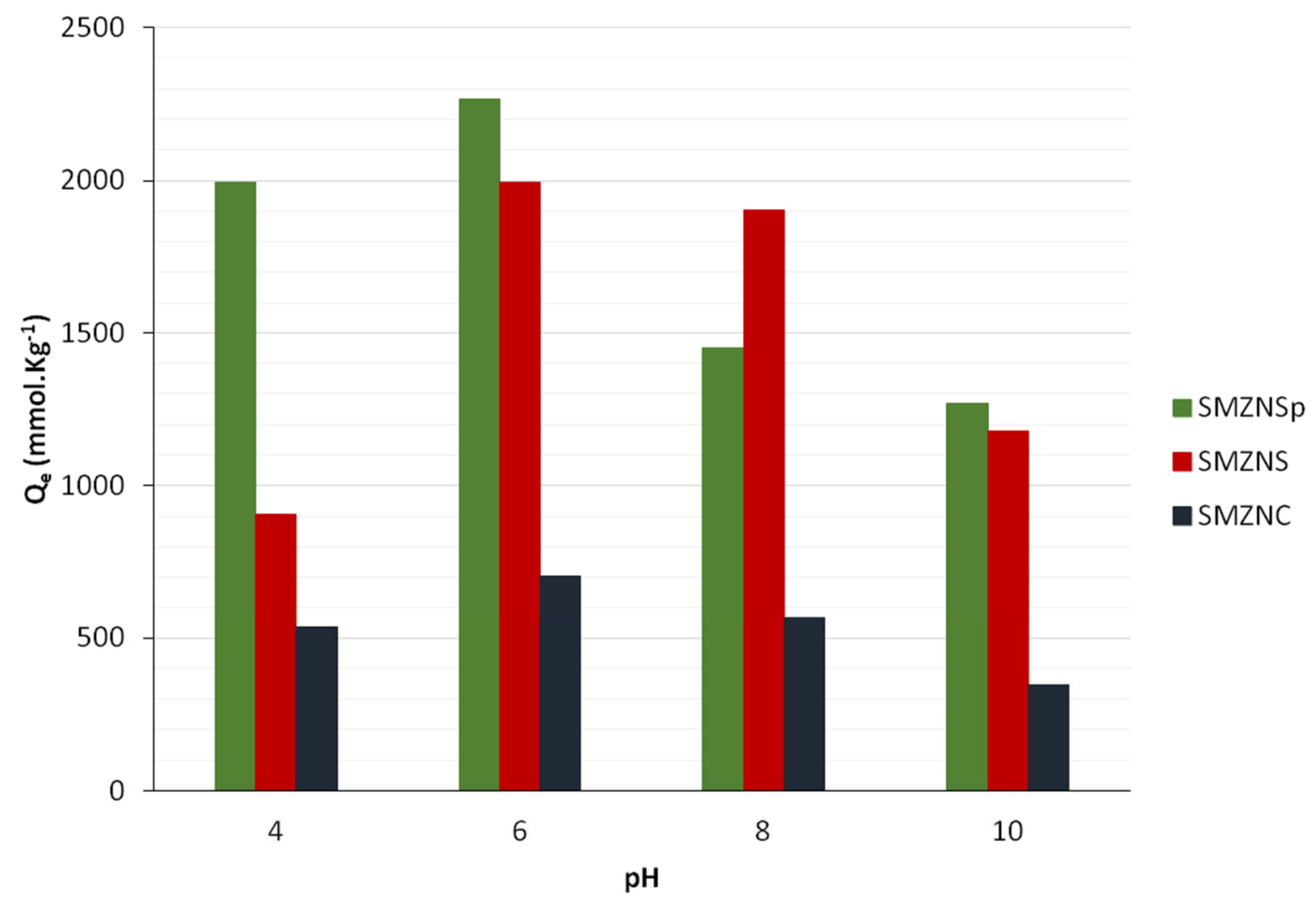

Figure 13. Effect of $\mathrm{pH}$ on the nitrate removal over $\mathrm{SMZ}_{\mathrm{NC}}, \mathrm{SMZ}_{\mathrm{NS}}$, and $\mathrm{SMZ} \mathrm{NSp}_{\mathrm{N}}$ with $\mathrm{S} / \mathrm{L}$ ratio of 0.5 $\mathrm{mg} \cdot \mathrm{mL}^{-1}$.

\section{Conclusion:}

In the present work, the effect of external surface area on surface modification for three nanosized MFI-zeolite materials was studied. ZSM-5 SMZ nanocrystals, nanosheets, and nanosponges were synthesized in different manners (with high solid/liquid ratio, low water volume, use of dual-porogenic surfactant) in order to obtain small crystals with high external surface areas. The surface of the studied zeolites were then modified by the use of a cationic surfactant "HDTMA ${ }^{+} \mathrm{Br}^{-“ "}$, characterized before and after treatment in order to follow the surface changes and used finally for nitrate removal in contaminated water. Nitrate removal capacities were found to increase, as expected, with the increase of the external surface areas. Adsorption isotherms of the $\mathrm{SMZ}_{\mathrm{NC}}, \mathrm{SMZ}_{\mathrm{NS}}$, and $\mathrm{SMZ}_{\mathrm{NSp}}$ were plotted in a large concentration range of nitrate [0.8-40.5] $\mathrm{mmol}^{-1} \mathrm{~L}^{-1}$ and fitted with Langmuir isotherm model, with a maximum nitrate removal capacities found to be $810( \pm 50), 1941( \pm 100), 2125( \pm$ 100) $\mathrm{mmol} . \mathrm{Kg}^{-1}$ respectively for the 3 samples at high nitrate concentrations $\left(19 \mathrm{mg} . \mathrm{L}^{-1}\right)$ and a 
$\mathrm{pH}$ of 6 . The removal kinetics are very fast compared to other materials having the same range of removal capacity [51], and fit the pseudo second-order model for these materials.

\section{ACKNOWLEDGMENTS:}

XRD measurements, $\mathrm{N}_{2}$ adsorption-desorption isotherms, X-Ray fluorescence, SEM, and TEM analysis were performed on the technical platforms of IS2M. The authors are very grateful to NOUALI Habiba, MICHELIN Laure, JOSIEN Ludovic and VIDAL Loic for their assistance.

This research did not receive any specific grant from funding agencies in the public, commercial, or not-for-profit sectors.

\section{References:}

[1] T.S. Thompson, Bull. Environ. Contam. Toxicol. 66 (2001) 64-70. https://doi.org/10.1007/s0012800206

[2] T.L. Ng, J. Wayland Eheart, M. ASCE, X. Cai, J.B. Braden, G.F. Czapar, J. Water Resources Plan. Management. 140 (2014) 112-120. https://doi.org/10.1061/(ASCE)WR.19435452.0000320

[3] P.N. Magee, Phil. Trans. R. Soc. Lond. B. 296 (1982) 543-550. https://doi.org/stable/4312259

[4] R. Walker, Food Addit. Contam. $7 \quad$ (1990) 717-768. https://doi.org/10.1080/02652039009373938

[5] C.H. Tate, K.F. Arnold, Water Quality and Treatement, sixth ed., McGraw-Hill Inc, New York, 1990.

[6] D. Majumdar, N. Gupta, 42 (2000) 28-39. Nitrate pollution of groundwater and associated human health disorders, Ind. J. Environ. Health.

[7] J. Ma, Y. Chen, G. Luo, J. Nie, Z. Guo, Y. Liu, L. Ma, AMB Express. 10 (2017) 7-3. https://doi.org/10.1186/s13568-016-0309-6

[8] Y.L. Deng, Y.J. Ruan, S.M. Zhu, X.Y. Han, Z.Y. Ye, G. Liu, M.M. Shi, AMB Express. 7 (2017) 113-120. https://doi.org/10.1186/s13568-017-0412-3

[9] E.S. Salama, M.B. Kurade, R.A.I. Abou-Shanab, M. El-Dalatony, J.S. Yang, B. Min, B.H. Jeon, Sustainable Energy Reviews. $79 \quad$ (2017) 1189-1211. https://doi.org/10.1016/j.rser.2017.05.091

[10] S. Ghafari, M. Hasan, M.K. Aroua, J. Hazard. Mater. 162 (2009) 1507-1513. https://doi.org/10.1016/j.jhazmat.2008.06.039

[11] F. Thalasso, A. Vallecillo, P. Garcia-Encina, F. Fdz-Polanco, Water Res. 156 (1997) 55-60. https://doi.org/10.1016/S0043-1354(96)00228-X

[12] S.C. Ahn, S.Y. Oh, D.K. Cha, J. Hazard. Mater. 156 (2008) 17-22. https://doi.org/10.1016/j.jhazmat.2007.11.104

[13] M. Kumar, S. Chakraborty, J. Hazard. Mater. 135 (2006) 112-121. https://doi.org/10.1016/j.jhazmat.2005.11.031

[14] Z. Yiping, D. Grant B, P. Long, Z. Quanlin, T. Yan, X. Wei, L. Bihuan, H. Wei, C. Lili, Y. Zhengfang, Sci. Total Environ. 598 (2017) 1140-1150. https://doi.org/10.1016/j.scitotenv.2017.04.071 
[15] Z. Parisa, S. Estatira, H. Saeed, M. Maryam, Iranian J. Toxicol. 11 (2017) 53-59. http://dx.doi.org/10.29252/arakmu.11.5.53

[16] L.W. Canter, Nitrates in groundwater. CPC Press. Norman, Oklahoma, 1997.

[17] K.S. Haugen, M.J. Semmens, P.J. Novak, Water Res. J. Environ. Sci. 36 (2002) 3497-3506. https://doi.org/10.1016/S0043-1354(02)00043-X

[18] Q. Meng, H. Chen, J. Lin, Z. Lin, J. Sun, J. Environ. Sci. 56 (2016) 254-262. https://doi.org/10.1016/j.jes.2016.10.010

[19] F. Rezvani, M.H. Sarrafzadeh, S. Ibrahimi, H.M. Oh, Environ. Sci. Pollut. Res. (2017) or Rezvani, F., Sarrafzadeh, MH., Ebrahimi, S. et al. Environ Sci Pollut Res (2017). https://doi-org.inc.bib.cnrs.fr/10.1007/s11356-017-9185-0

[20] G.M. Haggerty, R.S. Bowman, Environ. Sci. \& Technol. 28 (1994) 452-458. https://doi.org/10.1021/es00052a017

[21] M. Masukume, A. Eskandapour, M.S. Onyango, A. Ochieng, F. Otieno, Sep. Sci Technol. 46 (2011) 1131-1137. https://doi.org/10.1080/01496395.2010.551246

[22] Y. Zhan, J. Lin, Z. Zhu, J. Hazard. Mater. 186 (2011) 1972-1978. https://doi.org/10.1016/j.jhazmat.2010.12.090

[23] H. Guan, E. Bestland, C. Zhu, H. Zhu, D. Albertsdottir, J. Hustton, C.T. SimmonsM. Ginic-Markovic, X. Tao, A.V. Ellis, J. Hazard. Mater. 183 (2010) 616-621. https://doi.org/10.1016/j.jhazmat.2010.07.069

[24] J. Schick, P. Caullet, J.L. Paillaud, J. Patarin, C. Mangold-Callarec, Microporous Mesoporous Mater. 132 (2010) 395-400. https://doi.org/10.1016/j.micromeso.2010.03.018

[25] J. Schick, P. Caullet, J.L. Paillaud, J. Patarin, C. Mangold-Callarec, Microporous Mesoporous Mater. 142 (2011) 549-556. https://doi.org/10.1016/j.micromeso.2010.12.039

[26] Z. Li, S. Bowman, Water Res. 35 (2001) 3771-3776. https://doi.org/10.1016/S00431354(01)00120-8

[27] K. Na, C. Jo, J. Kim, K. Cho, J. Jung, Y. Seo, R.J. Messinger, B.F. Chmelka, R. Ryoo, American Association Adv. Sci. $333 \quad$ (2011) 328-332. https://doi.org/10.1126/science.1204452

[28] I. Kabalan, G. Rioland, H. Nouali, B. Lebeau, S. Rigolet, M.-B. Fadlallah, J. Toufaily, T. Hamieh, T. J. Daou, RSC Adv. 4 (2014) 37353 - 37358. https://doi.org/10.1039/C4RA05567E

[29] I. Kabalan, B. Lebeau, M.-B. Fadlallah, J. Toufaily, T. Hamieh, J. P. Bellat, T. J. Daou, J. Nanosci. Nanotechnol. 16 (2016) 1-5. https://doi.org/10.1166/jnn.2016.12884

[30] I. Kabalan, B. Lebeau, H. Nouali, J. Toufaily, T. Hamieh, B. Koubaissy, J. P. Bellat, T. J. Daou, J. Phys. Chem. 120 (2016) 2688-2697. https://doi.org/10.1021/acs.jpcc.5b10052

[31] S.K. Schnell, L. Wu, A.J.J. Koekkoet, S. Kjelstrup, E.J.M. Hensen, T.J.H. Vlugt. American Chem. Soc. 117 (2013) 24503-24510. https://doi.orga/10.1021/jp409316a

[32] J.C. Kim, S. Lee, K. Cho, K. Na, C. Lee, R. Ryoo. American Chem. Soc. 4 (2014) 3919-3927. https://doi.org/10.1021/cs500784v

[33] J.C. Kim, R. Ryoo, M.V. Opanasenko, M.V. Shamzhy, J. Cejka. https://doi.org/10.1021/cs502021a

[34] J. Schick, T.J. Daou, P. Caullet, J.L. Paillaud, J. Patarin, C. Mangold-Callarec, Chem. Comm. 47 (2011) 902-904. https://doi.org/10.1039/c0cc03604h

[35] L. El hanache, H. Nouali, B. Lebeau, T. Hamiye, J. Toufaily, T.J. Daou, J. Hazard. Mater. 364 (2019) 206-217. https://doi.org/10.1016/j.jhazmat.2018.10.015

[36] F. X. Van Leeuwen, B. Sangster, Crit. Rev. Toxicol. 18 (1987) 189-213. https://doi.org/10.3109/10408448709089861

[37] J. Dhainaut, T.J. Daou, Y. Bidal, N. Bats, B. Harbuzaru, G. Lapisardi, H. Chaumeil, A. Defoin, L. Rouleau, J. Patarin, Cryst. Eng. Comm. 15 (2013) 3009-3015. https://doi.orrg/10.1039/C3CE40118A 
[38] W. Li, T. Ma, Y. Zhang, Y. Gong, Z. Wu, T. Dou, Cryst. Eng. Comm. 17 (2015) 5680-5689. https://doi.org/10.1039/C5CE00637F

[39] M. Choi, K. Na, J. Kim, Y. Sakamoto, O. Terasaki, R. Ryoo, Nature. 461 (2009) 246249. https://doi.org.10.1038/nature08288

[40] J. Rouquerol, P. Llewellyn, F. Rouquerol, Stud. Surf. Sci. Catal. 160 (2007) 49-56. https://doi.org/10.1016/S0167-2991(07)80008-5

[41] J. Hrenovic, M. Rozic, L. Sekovanic, A. Anic-Vucinic, J. Hazard. Mater. 156 (2008) 576-582. https://doi.org/10.1016/j.jhazmat.2007.12.060

[42] S.T. Wilson, B.M. Lok, E. M. Flanigen, Application: EP43562, 1982.

[43] M. Thommes, K. Kaneko, A.V. Neimark, J.P. Olivier,F. Rodriguez-Reinoso, J. Rouquerol, S.W. Sing, Pure Appl. Chem. 87(2015) 1051-1069. https://doi.org/10.1515/pac2014-1117

[44] A. Galarneau, V. François, R. Jeremy, F. Fajula, B. Coasne, Langmuir. 30(2004) 13266-13274. https://doi.org/10.1021/la5026679

[45] J.G. Post, The characterization of ZSM-5: a physical, catalytic and spectroscopic study Eindhoven: Technische Hogeschool, Eindhoven, (1984).

[46] H. Freundlich, J. Phys. Chem. 57 (1906) 385-470. https://doi.org/10.12691/ijebb-4-24

[47] I. Langmuir, J. Am. Chem. Soc. 40 (1918) 1361-1403. https://doi.org/10.1021/ja02242a004

[48] A. Bhatnagara, E.Kumar, M. Sillanpää, Chem. Eng. J. 163 (2010) 317-323. https://doi.org/10.1016/j.cej.2010.08.008

[49] S. Langergren, Handlingar. 24 (1898) 1-39. https://doi.org/10.1007/bf01501332

[50] Y.S. Ho, G. Mckay, Process Biochem. 34 (1999) 451-465. https://doi.org/10.1016/S0032-9592(98)00112-5

[51] K. Hosni, E. Srasra, Inorganic Mater.44 (2008) $742-749$. https://doi.org./10.1134/S0020168508070121 

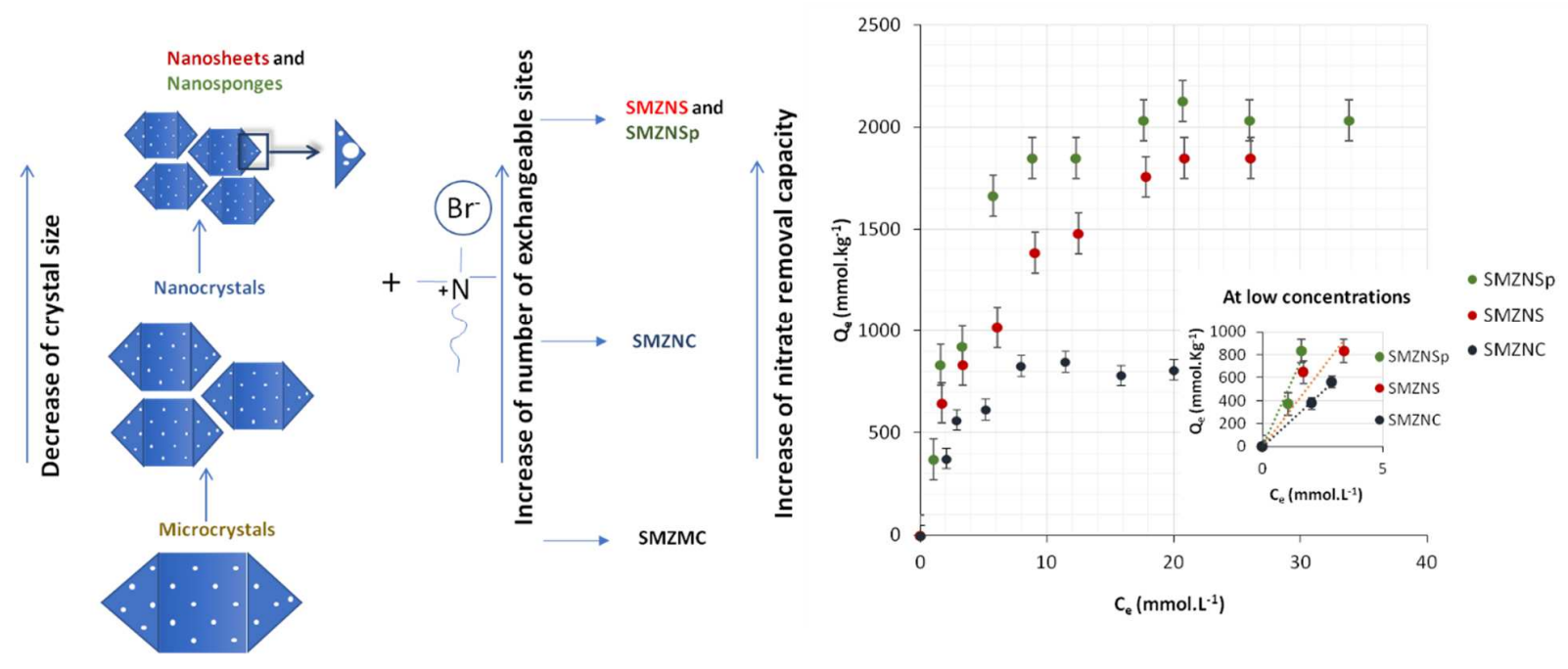

Ultra-fast Surfactant-Modified MFI-type Nanozeolites adsorbent systems for nitrate removal from contaminated water. 